Article

\title{
Flood Spatial Modeling in Northern Iran Using Remote Sensing and GIS: A Comparison between Evidential Belief Functions and Its Ensemble with a Multivariate Logistic Regression Model
}

\author{
Duie Tien Bui ${ }^{1,2}$, Khabat Khosravi ${ }^{3}$ (D), Himan Shahabi ${ }^{4} *\left(\mathbb{D}\right.$, Prasad Daggupati ${ }^{\text {, }}$ \\ Jan F. Adamowski ${ }^{6}$, Assefa M. Melesse ${ }^{7}$ (D), Binh Thai Pham ${ }^{8}$ (D) Hamid Reza Pourghasemi ${ }^{9}$ (D), \\ Mehrnoosh Mahmoudi ${ }^{10}$, Sepideh Bahrami ${ }^{11}$, Biswajeet Pradhan 12,13 ${ }^{(D)}$, Ataollah Shirzadi ${ }^{14}$ (D), \\ Kamran Chapi ${ }^{14}$ and Saro Lee ${ }^{15,16, * \text { D }}$
}

1 Geographic Information Science Research Group, Ton Duc Thang University, Ho Chi Minh City, Vietnam 2 Faculty of Environment and Labour Safety, Ton Duc Thang University, Ho Chi Minh City, Vietnam

3 Department of Watershed Management, Faculty of Natural Resources, Sari Agricultural Sciences and Natural Resources University, Sari, Sari Mazandaran 48181-68984, Iran

4 Department of Geomorphology, Faculty of Natural Resources, University of Kurdistan, Sanandaj 66177-15175, Iran

5 School of Civil Engineering, University of Guelph, Guelph, ON N1G 2W1, Canada

6 Department of Bioresource Engineering, Faculty of Agriculture \& Environmental Sciences, McGill University, Saint-Anne-de-Bellevue, QC H9X3V9, Canada

7 Department of Earth and Environment, Florida International University, Miami, FL 33199, USA

8 Institute of Research and Development, Duy Tan University, 550000 Da Nang, Vietnam

9 Department of Natural Resources and Environmental Engineering, College of Agriculture, Shiraz University, Shiraz 71441-65186, Iran

10 Applied Research Center, Florida International University, Miami, FL 33174, USA

11 Department of Hydrological Sciences, University of Nevada, Reno, NV 89557, USA

12 Center for Advanced Modeling and Geospatial System (CAMGIS), Faculty of Engineering and IT, University of Technology Sydney, CB11.06.106, Building 11, 81 Broadway, Sydney, NSW 2007, Australia

13 Department of Energy and Mineral Resources Engineering, Choongmu-gwan, Sejong University, 209 Neungdong-ro, Gwangjin-gu, Seoul 05006, Korea

14 Department of Range and Watershed Management, Faculty of Natural Resources, University of Kurdistan, Sanandaj 66177-15175, Iran

15 Geoscience Platform Research Division, Korea Institute of Geoscience and Mineral Resources (KIGAM), 124, Gwahak-ro Yuseong-gu, Daejeon 34132, Korea

16 Department of Geophysical Exploration, Korea University of Science and Technology, 217 Gajeong-ro Yuseong-gu, Daejeon 34113, Korea

* Correspondence: h.shahabi@uok.ac.ir (H.S.); leesaro@kigam.re.kr (S.L.); Tel.: +98-91-86658739 (H.S.); +82-42-8683057 (S.L.)

Received: 10 May 2019; Accepted: 19 June 2019; Published: 4 July 2019

\begin{abstract}
Floods are some of the most dangerous and most frequent natural disasters occurring in the northern region of Iran. Flooding in this area frequently leads to major urban, financial, anthropogenic, and environmental impacts. Therefore, the development of flood susceptibility maps used to identify flood zones in the catchment is necessary for improved flood management and decision making. The main objective of this study was to evaluate the performance of an Evidential Belief Function (EBF) model, both as an individual model and in combination with Logistic Regression (LR) methods, in preparing flood susceptibility maps for the Haraz Catchment in the Mazandaran Province, Iran. The spatial database created consisted of a flood inventory, altitude, slope angle, plan curvature, Topographic Wetness Index (TWI), Stream Power Index (SPI), distance from river, rainfall, geology, land use, and Normalized Difference Vegetation Index (NDVI) for the region. After obtaining the
\end{abstract}


required information from various sources, 151 of 211 recorded flooding points were used for model training and preparation of the flood susceptibility maps. For validation, the results of the models were compared to the 60 remaining flooding points. The Receiver Operating Characteristic (ROC) curve was drawn, and the Area Under the Curve (AUC) was calculated to obtain the accuracy of the flood susceptibility maps prepared through success rates (using training data) and prediction rates (using validation data). The AUC results indicated that the EBF, EBF from LR, EBF-LR (enter), and EBF-LR (stepwise) success rates were $94.61 \%, 67.94 \%, 86.45 \%$, and $56.31 \%$, respectively, and the prediction rates were $94.55 \%, 66.41 \%, 83.19 \%$, and $52.98 \%$, respectively. The results showed that the EBF model had the highest accuracy in predicting flood susceptibility within the catchment, in which $15 \%$ of the total areas were located in high and very high susceptibility classes, and $62 \%$ were located in low and very low susceptibility classes. These results can be used for the planning and management of areas vulnerable to floods in order to prevent flood-induced damage; the results may also be useful for natural disaster assessment.

Keywords: Flood spatial modeling; Evidential belief function; Logistic regression; Ensemble method; GIS; Iran

\section{Introduction}

A natural disaster is a major adverse event resulting from the natural processes of the Earth. These can include floods, hurricanes, tornadoes, volcanic eruptions, earthquakes, tsunamis, etc. A natural disaster can cause loss of life and damage to property, which typically results in economic damage, the severity of which depends on the affected population's resilience, or ability to recover, and also on the available infrastructure. Among natural disasters, floods are considered to be one of the most devastating [1], and an accurate assessment of its risks is hampered by a lack of data and knowledge about flood losses at different scales [2]. During a heavy rainfall event, the amount of flow discharge in a river increases rapidly and the water level will rise above its normal bed, covering the flood plain and surrounding areas [3]. Life-threatening water overflow in residential areas is a common occurrence in Iran after earthquakes (http://www3.irna.ir/fa/NewsPrint.aspx?ID=214943), and catastrophic flooding events happen annually in the Mazandaran, Guilan, and Golestan Provinces in Northern Iran. Due to the high flood-frequency in this region, to prevent loss of life and property damage, areas with a high risk of flooding must be recognized according to flood susceptibility maps [4]. The primary difference between flood susceptibility and flood inundation maps is that flood susceptibility maps (FSM) only show the areas that have a high potential for flooding, while flood inundation maps can identify flood-prone areas based on different flood depths [5,6].

On a global scale, floods are the most destructive natural disasters, causing the highest number of deaths and damage; in fact, Opolot [7] noted that almost 99 million people around the world were affected by floods between 2000 and 2008. In the most recent decade, the occurrence of repeated flood events in the northern part of Iran reached its historical maximum, with the rate and extent of damage increasing every year. Examples of recent floods in the Mazandaran Province and its cities include Noshahr City in 1995, 2003, and 2012, Neka City in 1999, Behshar City in 2013, and Sari City also in 2013. The flood in Neka City caused more than $\$ 1,000,000$ worth of damage to agricultural lands including wheat, barley, and rice fields. The arable lands of about 28 villages, with an area of 80 ha, were also destroyed in the Chahardangeh District, Sari, while 150 ha of agricultural lands were destroyed in Klijan Restagh in Sari City. Hence, identification and evaluation of sensitive areas are essential in order to prevent and mitigate flood damages and losses [4]. Hydrologists have used several models to prepare flooding maps, but many of these models are data intensive or difficult to calibrate; however, some of the models are still required to understand the physical processes occurring within the catchment [8]. 
In recent years, many statistical and probabilistic models have been tested to prepare flood susceptibility maps $[9,10]$. Geographic Information System (GIS) has been used as an effective tool for spatial analysis and data manipulation due to its ability to handle large amounts of spatial data [11]. Specifically, the combination of statistical and probabilistic models with Remote Sensing (RS) and GIS has been widely used by different researchers [1,12]. Additionally, some scientists and researchers have studied natural disasters, specifically floods and FSM, with the help of RS and GIS, using different models such as Decision-Tree (DT) [6,13], Support Vector Machine (SVM) [14,15], Frequency Ratio (FR) [16,17], Evidential Belief Function (EBF) [18-20], EBF-AHP (Analytical Hierarchy Process) [21], Logistic Regression (LR) [22], Shannon's entropy and weights-of-evidence [23], Artificial Neural Networks (ANN) [23], AHP [23,24], Random Forest [3,23], and Adaptive Neuro-Fuzzy Inference System (ANFIS) [25,26]. Recently, Khosravi et al. [27] compared the prediction power of the data mining algorithms of Naïve Bayes and Naïve Bayes Tree with three Multi-Criteria Decision-Making (MCDM) analysis techniques (VIKOR, TOPSIS, and SAW). Their finding show that although MCDM models could predict flood-prone areas, the data mining algorithms had a higher prediction power than MCDMs since MCDMs rely on expert opinion. Arabameri et al. [28] applied an EBF model to the generation of flood susceptibility maps and compared the results with FR, TOPSIS, and VIKOR models, concluding that the EBF model performed best.

Recently, hybrid machine learning methods have been applied to studies relating to the spatial prediction of natural hazards such as landslides [12,20,29-49], wildfires [50], sinkholes [51], droughts [52], gully erosion [53,54], and groundwater [55,56] and land/ground subsidence [12]. An advantage of the ensemble algorithms is that they have a higher goodness-of-fit and prediction accuracy than individual or single-based methods/algorithms.

Khosravi et al. [57] stated that (1) every model has its advantages and disadvantages, (2) model performance depends on the data, accuracy and model structure, and (3) there is no universal guideline specifying which model should be applied in any given scenario; therefore, several models should be applied and the best of them used for further analysis. According to the literature, many machine learning and data mining algorithms have recently been applied in the field of natural hazards assessment, however, there is no consensus among researchers with regard to which model is best. Some research shows that bivariate statistical models demonstrated better predictive power than both machine learning and data mining algorithms [23]; this is because machine learning and data mining algorithms are more complex and require an expert to perform accurate simulations. Therefore, bivariate models, which are very simple to run with similar or sometimes superior predictive power, can be used as adequate substitutes.

At present, the EBF method is rarely applied for flood analysis, though it has been used for other categories of natural disasters such as landslide susceptibility assessment [21,33,58], and land subsidence [12,59], as well as having been used to predict groundwater potential zones [19,60].

The main purpose of this research is to evaluate the possibilities of using the EBF method to generate flood susceptibility maps and to assess the strengths and weaknesses of this method, as EBF has rarely been used for floods but has shown high accuracy in previous studies involving natural hazards mapping. The specific objectives of the current study include, (i) determining the most significant factors in each model, (ii) application of a bivariate statistical model, EBF, to produce new ensemble models, in combination with a statistical model, LR, in order to generate a more accurate flood susceptibility map, (iii) detection of the flood-prone areas within the study region for improved management during flood occurrence. In general, river flooding is a common natural disaster in the southern Caspian Sea, especially in the Haraz catchment; the results of the current study will be useful for land-use planning and management for future flood mitigation in the Haraz Watershed.

\section{Study Area}

The Haraz Catchment is located between the longitudes of $51^{\circ} 43^{\prime}$ to $52^{\circ} 36^{\prime} \mathrm{E}$ and the latitudes of $35^{\circ} 45^{\prime}$ to $36^{\circ} 22^{\prime} \mathrm{N}$. The study area lies south of Amol City, Mazandaran Province, Iran (Figure 1) and 
has an area of $4014 \mathrm{~km}^{2}$. The minimum and maximum elevations are 300 and $5600 \mathrm{~m}$, respectively. Average annual rainfall in the region was $723.07 \mathrm{~mm}$ in 2006 and $831.38 \mathrm{~mm}$ in 2012. The important residential centers of the Haraz Catchment are Polur, Tashal, Tiran, Rineh, Kandovan, Abasak, Gaznak, Baladeh, and Noor. The main causes of flooding in these areas include high-intensity rainfall over a short time-period, land-use changes in rangelands (e.g., deforestation or conversion of agricultural land and garden to residential areas), and the lack of effective management to prevent flooding. The maximum rainfall occurs in January, February, March, and October; with October being the wettest month with an average rainfall of $160 \mathrm{~mm}$ [61].

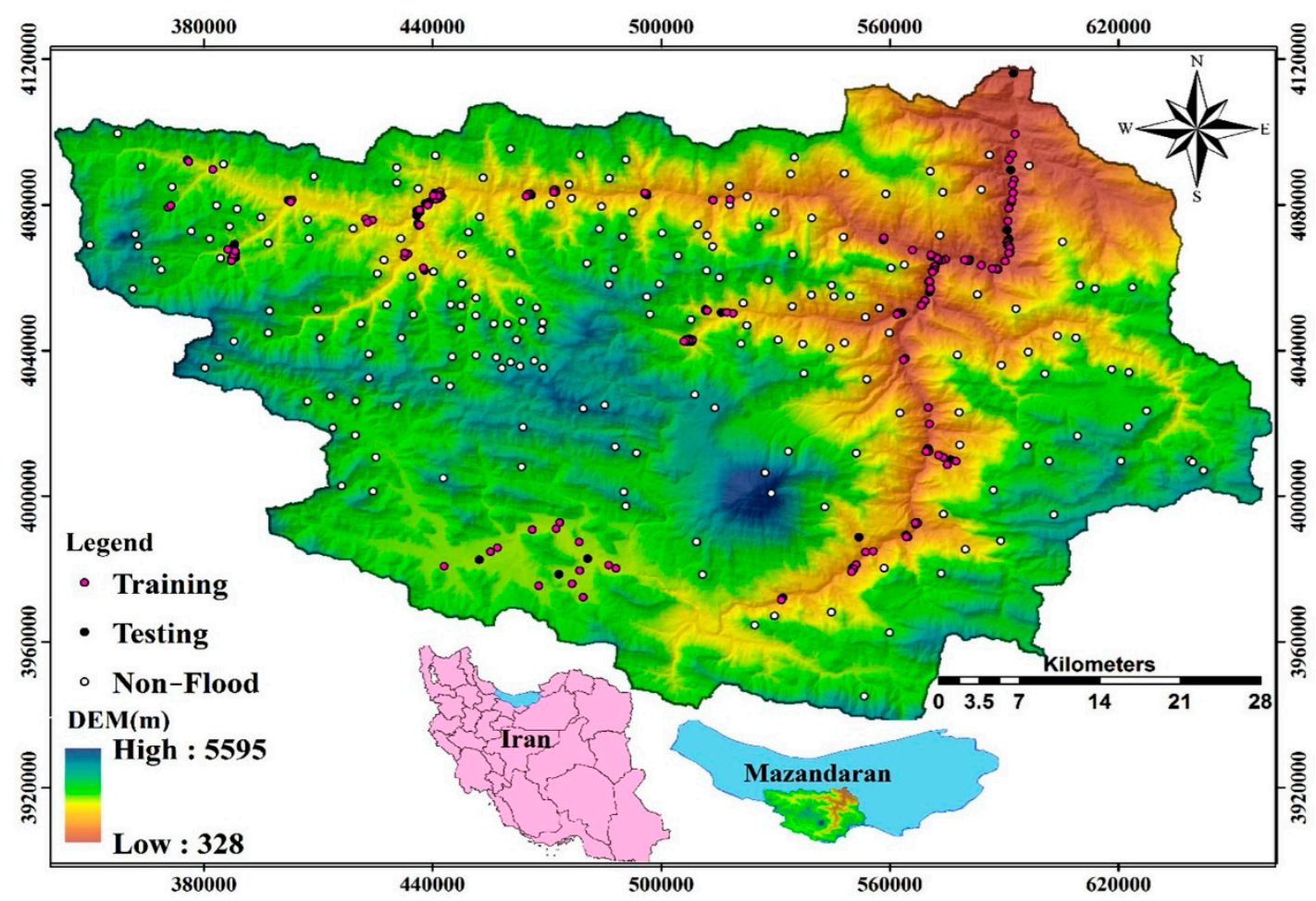

Figure 1. Flood locations mapped on a hill-shaded map of the Haraz Catchment, Iran.

\section{Methodology}

\subsection{Data Used}

\subsubsection{Flood Inventory Map}

To estimate the incidence of future floods in the study area, it is essential to analyze the occurrence of previous floods [62]. The accuracy of historical flood data has a strong influence on the legitimacy of predictive flood-potential mapping [63]. In this study, the flood inventory map was prepared based on data from flood events occurring in the years 2004, 2008, and 2012 (Mazandaran Regional Water Organization); this data was obtained through analysis of historical documentation, aerial photographs, and field surveys. In total, 211 flooding locations and 211 non-flooding locations were selected. A 'non-flooding location' refers to an area with relatively high elevation (e.g., hills and mountains) that is not affected by flooding, and these points were identified using a topographic map and Google Earth [64]. The resultant flood inventory map was then divided into two parts for training (151 flood locations, 70\% of sampled land area) and validation (60 flood locations, 30\% of sampled land area) randomly [65]. Selected photos of floods in the northern part of the country are shown in Figure 2a-c. 

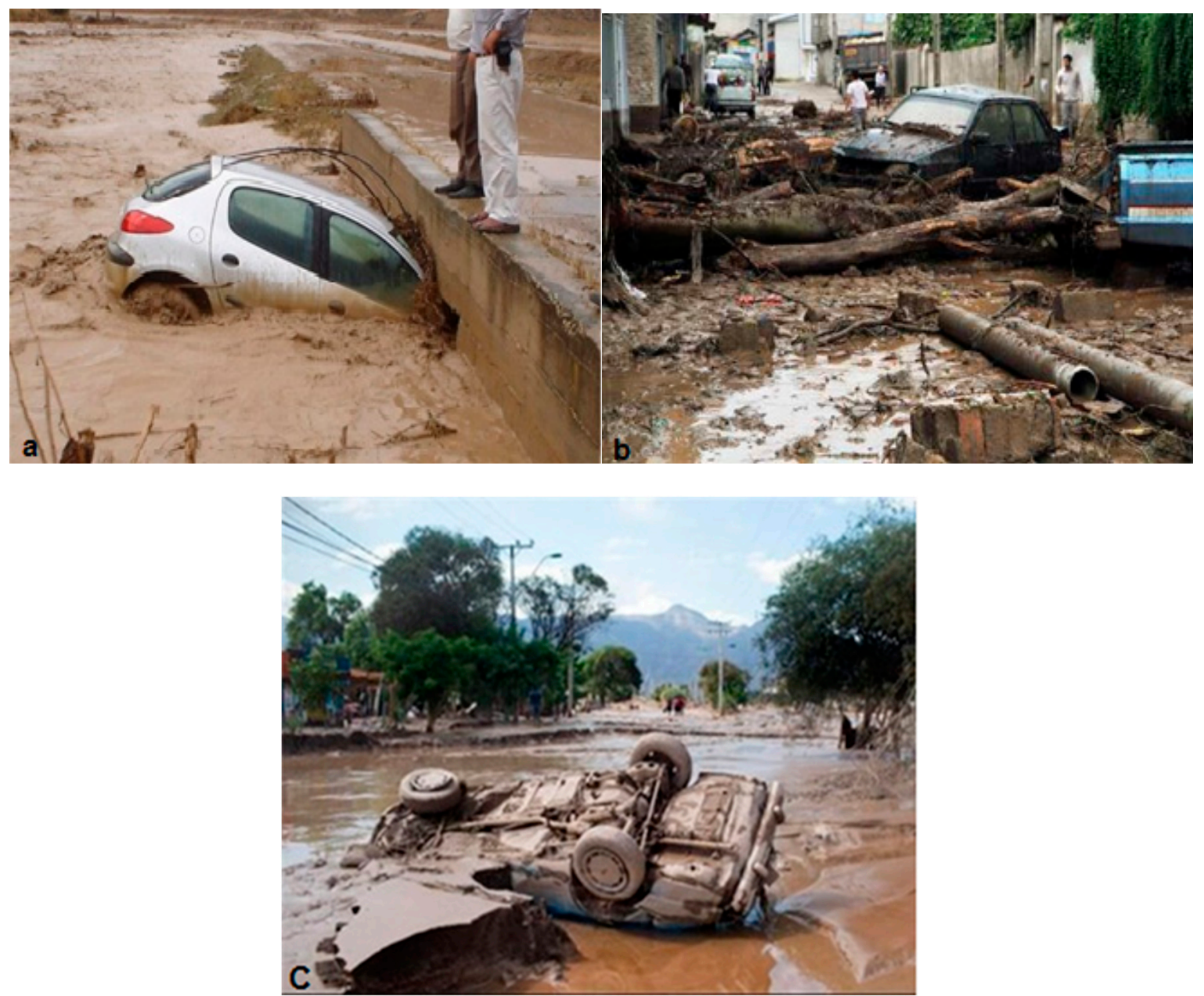

Figure 2. (a) Flood in Surkh Rod and Mahmoud Abad, on April 12, 2015, (b) flood in Neka on September 12, 2012, (c) flood in Behshahr on September 16, 2013.

\subsubsection{Multicollinearity Diagnosis}

After determining the flood-conditioning factors, it is important to consider potential problems associated with multicollinearity between independent variables [65]. If multicollinearity in the regression equation is high, it means that there is a high correlation between independent variables (inter-dependent) and, despite a high $\mathrm{R}^{2}$, the model will not have a high validation accuracy. The exponent of the linear relationship between independent variables of the model is measured by an index that is called the tolerance, which is between 0 and 1. The Variance Inflation Factor (VIF) and tolerance are the most important indicators to consider when attempting to detect multicollinearity [66]. A tolerance of less than 0.2 or a VIF greater than 5 indicates a multicollinearity problem [66].

\subsubsection{Flood-Conditioning Factors}

In susceptibility mapping for floods or other natural disasters, it is necessary to define a series of conditioning factors $[5,67]$. In this study, ten conditioning factors were applied. Altitude, slope angle, plan curvature, the topographic wetness index (TWI) and stream power index (SPI) were derived from the ASTER Global DEM (ASTER GDEM) (https://gdex.cr.usgs.gov/gdex/), while distance from river, rainfall, geology, land-use, and Normalized Difference Vegetation Index (NDVI) were prepared from Operational Land Imager (OLI) of Landsat 8 image (Table 1) and then converted into $28 \times 28 \mathrm{~m}$ cell sizes based on a Digital Elevation Model (DEM). 
Table 1. Factors used in spatial modeling for flood susceptibility assessment in the study area.

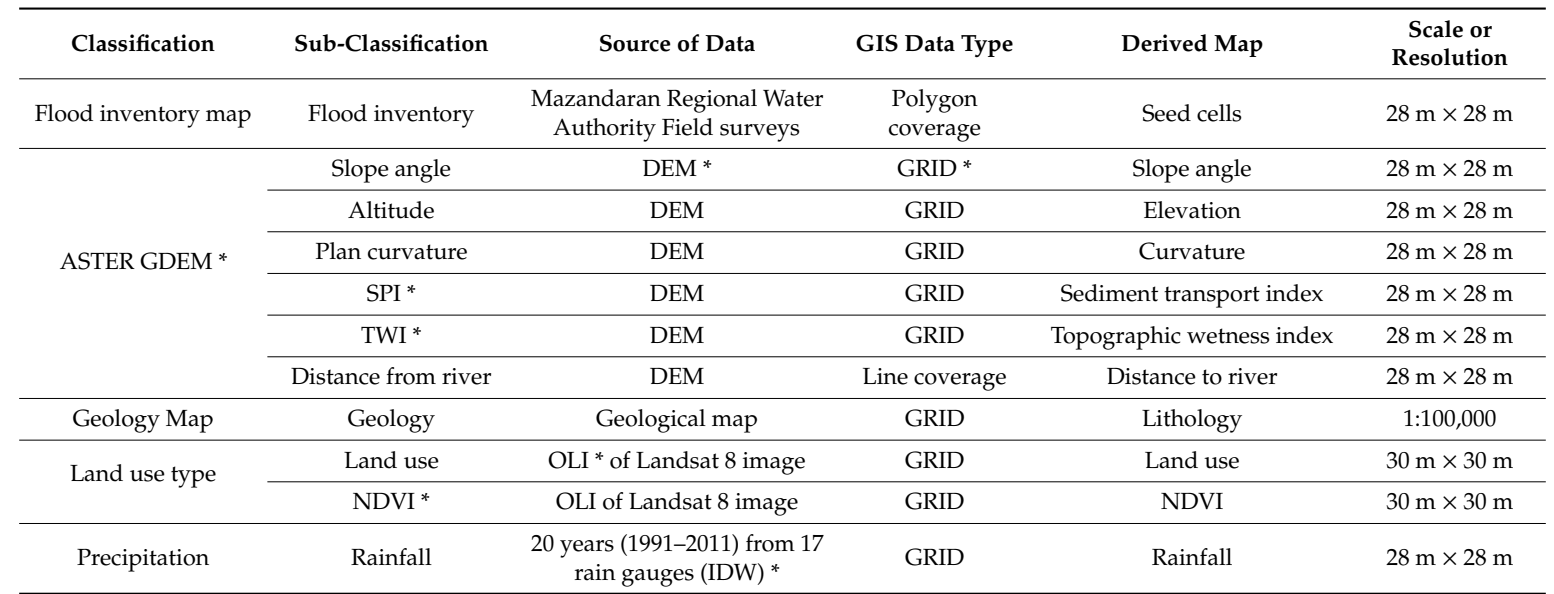

* GRID (graphic design); ASTER GDEM (ASTER Global DEM); DEM (Digital Elevation Model); NDVI (Normalized Difference Vegetation Index); TWI (Topographic Wetness Index); SPI (Stream Power Index); OLI (Operational Land Imager); IDW (Inverse Distance Weighting).

Topographic Factors

A DEM with a spatial resolution of $28 \times 28 \mathrm{~m}$ was used to provide primary and secondary features such as altitude (Figure 3a), slope angle (Figure 3b), and plan curvature (Figure 3c) in ArcGIS 10.1. Altitude, slope angle, and plan curvature factors were classified into nine, five, and three classes, respectively [18], based on a natural break classification scheme [68]. Flat areas with low slope and low altitude classes have a higher potential for flooding.

Water-Related Factors

Factors such as the topographic wetness index (TWI) and stream power index (SPI) were prepared using a DEM in the SAGA-GIS 2.8 software. TWI is the accumulation of flow at any location in the catchment, with consideration of downstream flow trends due to gravity [69]. Equation (1) was proposed by Moore et al. [70] to calculate the TWI:

$$
T W I=\ln \left(A_{S} / \tan \beta\right)
$$

where $A_{S}$ is the specific area of the catchment in $\mathrm{m}^{2} / \mathrm{m}$ of the catchment and $\beta$ is the slope angle in degrees. The TWI map is shown in Figure 3d. Figure 3e shows the SPI, which is the measurement of the erosive power of water flow, which is shown in Equation (2) [70]:

$$
S P I=\left(A_{S} \times \tan \beta\right)
$$

To create the layer for the distance from the river factor, the digital map of the river was edited using the multi-ring buffer command in ArcGIS 10.1. Subsequently, this layer was divided into six classes: 500, 1000, 1500, 2000, 2500, and $>2500 \mathrm{~m}$ (Figure 3f). Distance from the river (or distance of the measurement points from the river) has a major role in the distribution and magnitude of floods in the area [71]. In the northern part of Iran, as a result of insufficient infiltration and percolation due to changes in soil characteristics, vegetation coverage, and ground surface slope, high-intensity rainfall events generate large amounts of runoff in the vicinity of the nearby river, causing catastrophic flood events in downstream areas with lower topographic gradients [72]. 

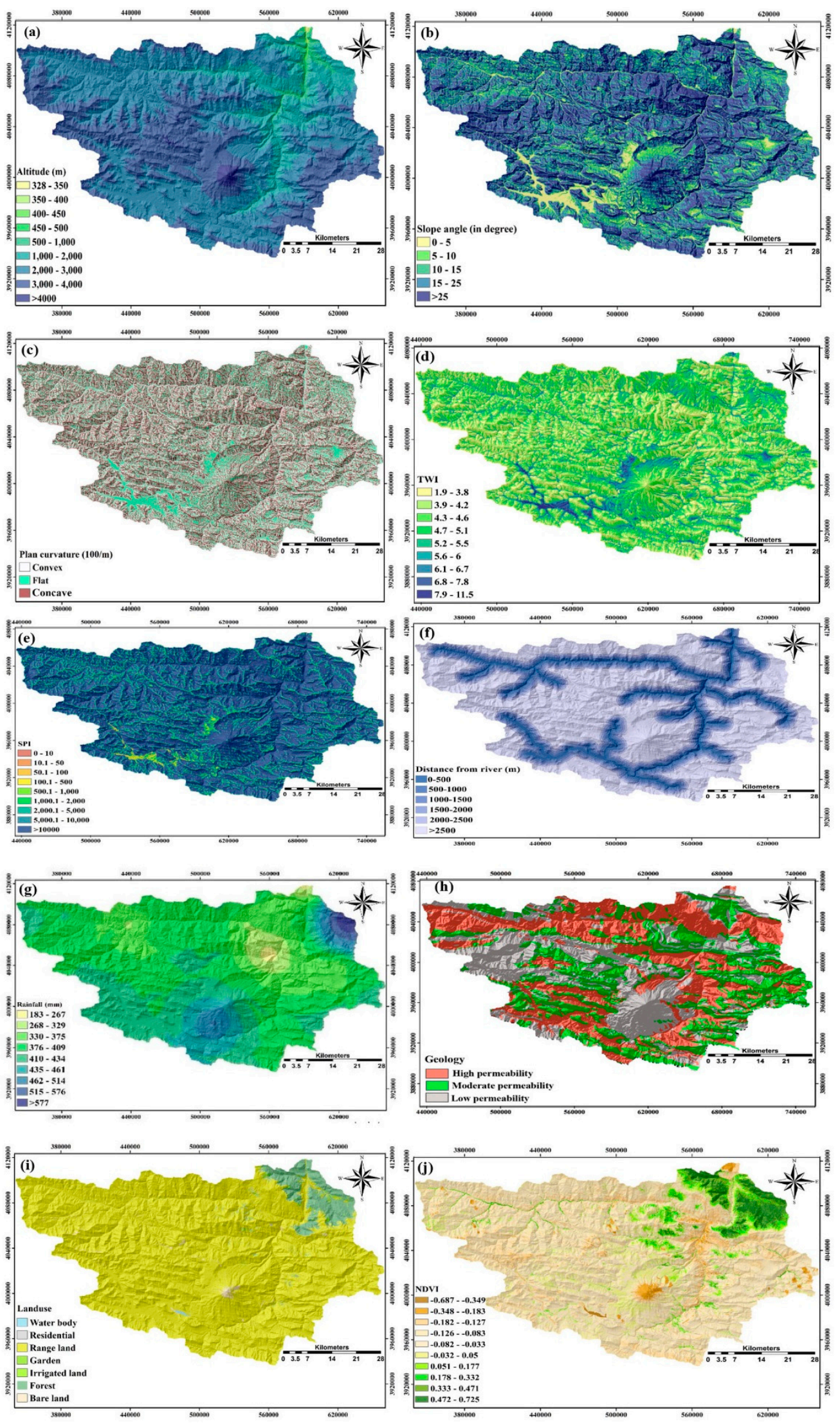

Figure 3. Flood-conditioning factors of the study area: (a) Altitude (m), (b) Slope angle (In degrees), (c) plan curvature (100/m), (d) topographic wetness index (TWI), (e) Stream power index (SPI), (f) distance from river (m), (g) rainfall (mm), (h) geology, (i) land use, and (j) NDVI. 
Twenty years of rainfall data (1991-2011) from 17 stations inside and outside of the study area were used to generate an annual rainfall map. Several interpolation methods, such as kriging (simple and ordinary), inverse distance weighting (IDW) with a power of 1 to 5 , radial function with kernel functions of completely regularized spline and spline with tension, were compared to find the best method for mapping the rainfall data. The simple kriging method was selected as the best method because it produced the lowest Root Mean Square Error (RMSE) and Mean Absolute Error (MAE) [16]. The rainfall map of the study area was ultimately divided into nine classes [73] (Figure 3g).

Physical Factors

In general, geology plays a significant role in flood susceptibility due to the variable sensitivity of lithological units. Areas with hard and resistant rocks, as well as highly-permeable soils, have low channel densities [74,75]. The geology layer of the study area, in GIS shapefile format, was obtained from the Mazandaran Regional Water Organization and was originally prepared by the Geological Survey Department in Iran.

The ability of rock formations to resist chemical and mechanical weathering were classified according to the degree of permeability, into low, moderate, and high classes [76]. Finally, the geological map of the study area was classified into three groups $[16,77]$ and is presented in Figure $3 \mathrm{~h}$ and Table 2.

The land-use and NDVI maps were prepared using satellite images from Landsat 8 OLI (taken from the National Geography Organization of Iran) from 2013. The land-use map was classified into seven categories, consisting of rangeland, bare land, forest, garden, irrigated land, residential areas, and water-bodies; this was done using a Neural Network Algorithm (ANN) and through supervised classification in Environment for Visualizing Images (ENVI 5.1) software (Figure 3i).

The NDVI map shows the surface coverage of live vegetation. The vegetation index exists as a proportional output between -1 and +1 . The NDVI values (Figure $3 j$ ) were calculated using Equation (3) [78]:

$$
N D V I=(N I R-V I S) /(N I R+V I S)
$$

where VIS and NIR are the spectral reflectance measurements acquired in the red and near-infrared bands of the electromagnetic spectrum, respectively.

All of the aforementioned flood conditioning factors were converted to a grid comprised of $28 \times$ $28 \mathrm{~m}$ cells.

\subsection{Application of Models}

Flood susceptibility analyses are highly important studies in the field of river hydrology [64,79]. In this study, the flood susceptibility analysis was carried out using EBF, EBF from LR, EBF-LR (Enter) and EBF-LR (Stepwise) methods. Four steps were taken to prepare the flood susceptibility maps of the study area: (1) Data was collected, and a spatial database of conditioning factors associated with flood occurrences was created, (2) the relationship between conditioning factors and flood locations was determined, (3) flood susceptibility maps were prepared using the different algorithms, and (4) the results were validated using success and prediction-rate curves and visual interpretation. The methodology of this research is presented as a flowchart in Figure 4. 
Table 2. The lithology of the Haraz Catchment.

\begin{tabular}{|c|c|c|c|}
\hline Lithology & Formation & Code & Permeability \\
\hline Rockfall & - & Qf & Low \\
\hline Basic flow, pyroclastics & - & $\widehat{\mathrm{Pv}}$ & Low \\
\hline Rocks, marl, conglomerate, Paleocene & Dorud & $\mathrm{Pd}$ & Low \\
\hline Rocks, marl, conglomerate, Paleocene & Fajan & Pecf & Low \\
\hline Thick dolomite to form massive, limestone & Elika & $\mathrm{TRe} 2$ & Low \\
\hline Mafic volcanic rocks & - & TRv3 & Low \\
\hline Gabbro & - & $\mathrm{Tgb}$ & Low \\
\hline Basalt & - & $\mathrm{Kv}$ & Low \\
\hline Basalt, diabase, pyroclastic rocks and pyroclastic volcanic rocks & - & Kv1 & Low \\
\hline Tuff, basaltic andesite pyroclastic & - & Kv2 & Low \\
\hline Cut from multiple sources, Paland formation & Paland & $\mathrm{TRb}$ & Low \\
\hline Basalt and olivine & - & Qv1 & Low \\
\hline Agglomerate and andesite tuff & - & Qv2 & Low \\
\hline Damavand magma, Andesite trachyte & - & Qv3 & Low \\
\hline Quartz-Diorite & - & $\hat{\mathrm{Qd}}$ & Low \\
\hline Rhyolite & - & $\widehat{\mathrm{Rh}}$ & Low \\
\hline Trachyte & Eilka & $\mathrm{TR}$ & Low \\
\hline Dacite & - & da & Low \\
\hline Middle tuff member: pyroclastics & Karaj & Ekt2 & Low \\
\hline Trachyandesite, trachybasalt, basanite & Karaj & Evkt2 & Low \\
\hline Pyroclastic and andesite & Karaj & EA & Low \\
\hline Dacite, pyroclastic & - & Ezt2 & Low \\
\hline Tuff, volcanic rock & Karaj & Ek & Low \\
\hline Scree, talus fans & - & Qs & Moderate \\
\hline Scree & - & Qsc & Moderate \\
\hline Marine conglomeratic terraces & - & Qt & Moderate \\
\hline A thin layer of cream limestone, shale, limestone, Elika formation & Elika & TRe1 & Moderate \\
\hline Sandstone, shale, limestone, quartzite, make peace & Fajan & Pefvmc & Moderate \\
\hline Limestone, marly and sandy shales & Nesen & Pn & Moderate \\
\hline Fusulina limestone, dolomitic limestone & Ruteh & $\operatorname{Pr}$ & Moderate \\
\hline Santonian limestone & - & K21 & Moderate \\
\hline Limestone, marl, limestone, silty marl & - & K2plm & Moderate \\
\hline Cast locally with the layers of dolomitic limestone and shale & - & $\mathrm{Kgl}$ & Moderate \\
\hline Limestone and marl & - & $\mathrm{Kl}-\mathrm{m}$ & Moderate \\
\hline Orbitolina Limestone & Tiz Kuh & Klt & Moderate \\
\hline Nummulitic limestone & Ziarat & $\mathrm{Ez}$ & Moderate \\
\hline Conglomerate & Fajan & Ef & Moderate \\
\hline Old terraces & - & Qt1 & High \\
\hline Undifferentiated Quaternary deposits & - & $\widehat{Q}$ & High \\
\hline Loose alluvium in the river channels & - & Qal & High \\
\hline Landslide & - & Qlan & High \\
\hline Moraines (glacial deposits) & - & $\widehat{Q} \mathrm{~m}$ & High \\
\hline Calcareous and siliceous shales & Karaj & Eksl & High \\
\hline Younger gravel fans and terraces & - & Qt2 & High \\
\hline Loess & - & Qt2c & High \\
\hline Sinter deposits & - & Qtr & High \\
\hline Marl & Mila & E-m & High \\
\hline Gypsum & Kand & $\mathrm{Eg}$ & High \\
\hline
\end{tabular}




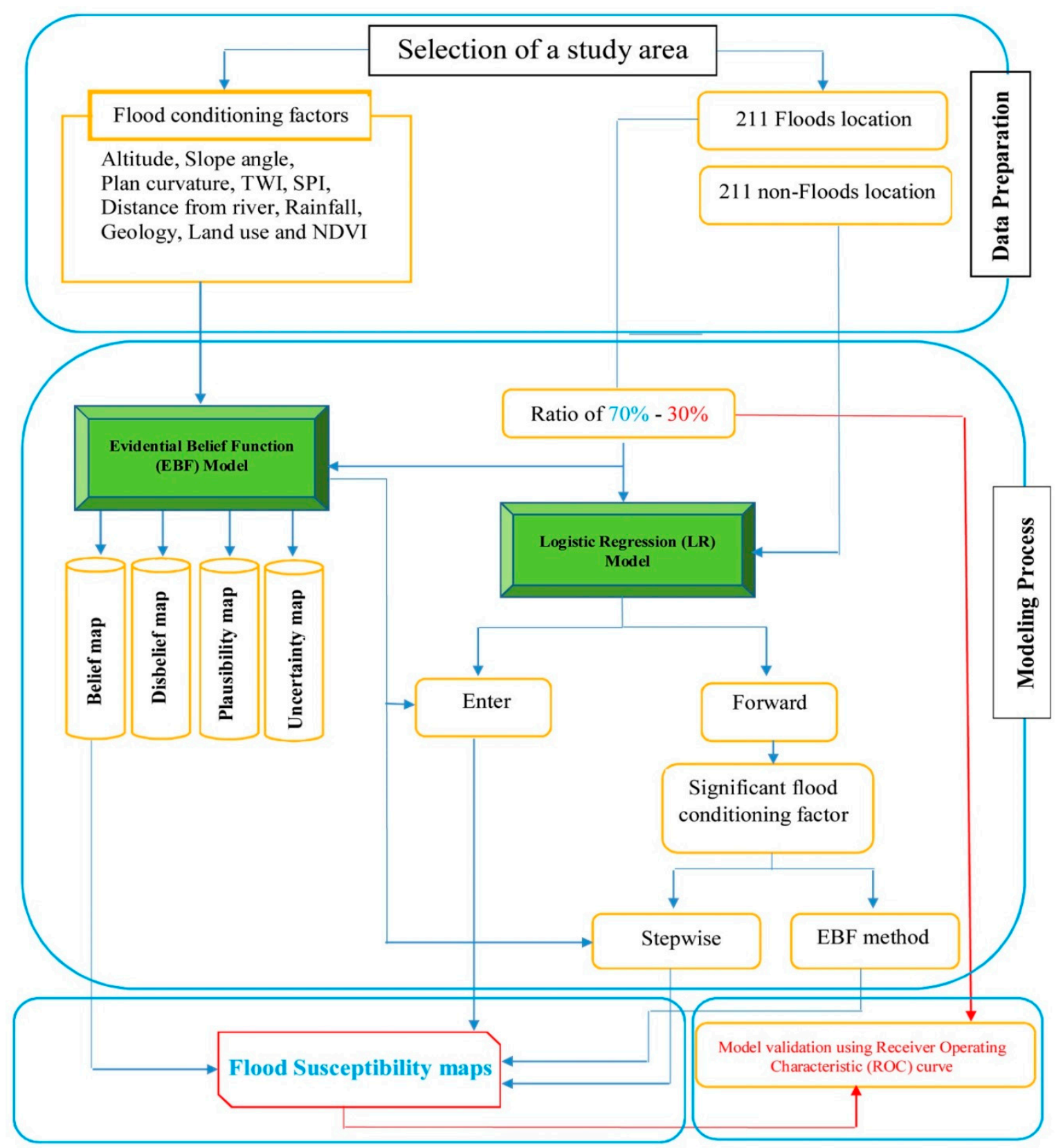

Figure 4. Flow chart of the adopted research methodology used to create flood susceptibility maps of the Haraz Catchment.

\subsubsection{Evidential Belief Function (EBF) Model}

The EBF model is based on the Dempster-Shafer Theory of Evidence [80,81]. Therefore, to implement the EBF model, the layers of the conditioning factors were transformed into evidential data layers and then integrated using knowledge of the spatial relationships between the flood occurrences and factors influencing the flooding in order to generate a predictive Flood Susceptibility Index (FSI) map. One of the advantages of this model is that both the predicted flood and flooding zone outputs exist within the same degree of uncertainty [82]. The EBF model is composed of four functions, namely: Bel (degree of Belief), Dis (degree of Disbelief), Unc (degree of Uncertainty) and Pls (degree of Plausibility) $[18,83]$. Four maps of Bel, Dis, Pls, and Unc were used for the assessment of the ten factors influencing flooding. Each map shows the probability of flood occurrences. The integration of 
all the factors shows the level of prediction accuracy. The EBF model was run using the following steps [84]. Equations (5) and (6) show how to achieve the results of Bel:

$$
\begin{gathered}
\lambda(T p)=N / D=[N(\text { LIEij }) / N(L)] /[N(E i j)-N(\text { LIEij }) /(N(A)-N(L)] \\
\left.B e l=\lambda(T p) E i j / \sum \lambda(T p) E i j\right)
\end{gathered}
$$

where, $N(L \cap E i j)$ is the number of flood pixels in each class, $N(L)$ is the total number of floods, $N(E i j)$ is the number of pixels of each class, $N(A)$ is the total pixels, and $N$ and $D$ are the proportions of flood event areas and non-flood areas, respectively.

Similarly, Dis values were also obtained through Equations (7) and (8), as shown below:

$$
\begin{gathered}
\lambda(T \bar{p}) E i j=K / H=[(N(L)-N(L \cap E i j)) / N(L)] /[N(A)-N(L)-N(E i j) /(N(A)-N(L)] \\
D i s=\lambda(T \bar{p}) E i j /\left(\sum \lambda(T \bar{p}) E i j\right)
\end{gathered}
$$

where $K$ is the proportion of flooding that does not occur, and $H$ is the proportion of non-flooding occurrence areas in other attributes outside the class.

Equations (4) and (6) were applied for all classes of factors influencing floods, and Equations (5) and (7) were used for Bel and Dis results. According to Dempster [80], the main part of the Theory of Evidence is provided by Bel being equal to the lower probability and Pls being equal to the upper probability; therefore, Pls is greater than or equal to Bel. According to Althuwaynee et al. [18], the three primary functions associated with the theory of Dempster-Shafer are as follows (1) Basic probability assignment function (BPA), (2) Belief function (Bel), and (3) Plausibility function (Pls). Generally, the other parameters were calculated, as shown in Equations (8), (9), and (10):

$$
\begin{gathered}
\text { Pls }- \text { Bel }=\text { Unc } \\
\text { Dis }=(1-\text { Pls }) \text { or }(1-\text { Unc }) \\
\text { Bel }+ \text { Unc }+ \text { Dis }=1
\end{gathered}
$$

\subsubsection{Logistic Regression (LR) Model}

Logistic regression is one of the Multivariate Statistical Analysis (MSA) models, which considers several parameters (e.g., slope, altitude, and plan curvature) that may affect the likelihood of flooding $[85,86]$. The purpose of using an LR model in this study was to determine the appropriate model for defining the relationships between the dependent variable and the factors affecting floods, in order to generate coefficients for each variable [87]. Therefore, in this study, $70 \%$ of the flood training points and ten flood-conditioning factors were entered into the model as the dependent and independent variables, respectively [88]. Statistical Package for Social Science software (SPSS18) was used to run the LR model using the Forward Conditional (stepwise) and Enter methods. In the Forward method, variables were entered into the model individually, and the results were evaluated based on the correlation between flood occurrence and individual variables; if there were no significant correlation, then the variable would be eliminated from the model [89]. The Forward Conditional calculations were based on significant probability (Sig) in the LR model, with Sig $<0.05$ indicating that the flood conditioning factor or independent variable had a statistically significant impact on flooding [73]. In the Enter method, all factors were entered into the model regardless of their correlation with flood occurrence. One of the advantages of LR models is that the data do not require a normal distribution, and the conditioning factors can be either continuous or discrete. Quantitatively, the 
relationship between flood occurrence and its dependency on several independent variables can be computed using Equation (11) as follows [19]:

$$
P(\text { event })=\frac{e^{Z}}{\left(1+e^{Z}\right)}
$$

where $P$ is the probability of an occurrence. As the value of $Z$ changes from $-\infty$ to $+\infty$, the probability of occurrence fluctuates between 0 and $1 . Z$ is the linear combination function of affecting factors (Equation (12)) that indicate the linear relationship, and b0 is the cutoff value of the model.

$$
Z=b_{0}+b_{1} x_{1}+b_{2} x_{2}+\ldots+b_{n} x_{n}
$$

The general equation of an LR model is given by Equation (13):

$$
Y=\operatorname{Logit}(p)=\ln \left(\frac{p}{1-p}\right)=b_{0}+b_{1} x_{1}+b_{2} x_{2}+\ldots+b_{n} x_{n}
$$

where $Y$ is the probability of flooding, $b_{n}(i=0,1, \ldots, n)$ are the estimated coefficients from the sample data, $n$ is the number of independent variables, and $X_{n}(i=0,1, \ldots, n)$ are the independent variables. Using an LR model individually may be insufficient since this model lacks the capacity to weight each factor [73]; therefore, the EBF and LR models were combined to assess the probability of flooding events in the study area.

\subsection{Validation of the Models}

Validation of the developed maps is an essential step in the identification of flood-prone areas, as well as in the determination of map quality [90]. Without validated maps, the models and their results would have no scientific significance $[19,91]$. In this study, the receiver operating characteristics (ROC) curve was used for model validation. The area under the ROC curve (AUC) was used for the evaluation and quantitative comparison of the methods used for flood susceptibility mapping. In this study, 70\% of the chosen flood locations were used for model training, and the remaining 30\% were used for model validation. The results of the developed flood susceptibility maps (FSMs) were compared with existent flood positions using success-rate and prediction-rate curves [91], and their accuracy was evaluated.

\section{Results}

\subsection{Flood Susceptibility Mapping Using the EBF Model}

The EBF model was used to determine the level of correlation between the flood occurrences and flood factors (Table 3). The results of this model showed the impact of each factor's class on a flood event. For example, an analysis of elevation illustrated that flooding occurs only at lower elevations, specifically, in the 3000-4000 m and $>4000 \mathrm{~m}$ classes, no flooding occurred. Moreover, the first two classes on the slope angle map had the highest number of flood points (i.e., were most likely to experience flooding), meaning that areas with low slope and low altitude are more susceptible to flooding. Results of the plan curvature analysis showed that the greatest impact on flood susceptibility was represented by a concave curvature, followed by a flat curve, which both represented high impacts, finally, a convex curvature which represented a small impact. 
Table 3. Spatial relationships among conditioning factors and flooding occurrence extracted by the EBF method.

\begin{tabular}{|c|c|c|c|c|c|c|c|c|c|}
\hline Factor & Class & $\begin{array}{l}\text { No. of Pixels } \\
\text { in Domain }\end{array}$ & $\begin{array}{l}\text { Percentage } \\
\text { of Domain }\end{array}$ & $\begin{array}{l}\text { No. of } \\
\text { Floods }\end{array}$ & $\begin{array}{l}\text { Percentage } \\
\text { of Floods }\end{array}$ & Bel & Dis & Unc & Pls \\
\hline \multirow{9}{*}{ Altitude (m) } & $328-350$ & 112 & 0.02 & 0 & 0.00 & 0.000 & 0.108 & 0.892 & 0.892 \\
\hline & $350-400$ & 242 & 0.04 & 0 & 0.00 & 0.000 & 0.108 & 0.892 & 0.892 \\
\hline & $400-450$ & 466 & 0.08 & 2 & 1.32 & 0.255 & 0.107 & 0.638 & 0.893 \\
\hline & $450-500$ & 651 & 0.11 & 5 & 3.31 & 0.458 & 0.104 & 0.438 & 0.896 \\
\hline & 500-1000 & 11,230 & 1.98 & 46 & 30.46 & 0.243 & 0.077 & 0.680 & 0.923 \\
\hline & 1000-2000 & 78,535 & 13.82 & 43 & 28.48 & 0.032 & 0.090 & 0.878 & 0.910 \\
\hline & 2000-3000 & 282,516 & 49.70 & 55 & 36.42 & 0.012 & 0.136 & 0.852 & 0.864 \\
\hline & $3000-4000$ & 188,954 & 33.24 & 0 & 0.00 & 0.000 & 0.162 & 0.838 & 0.838 \\
\hline & $>4000$ & 5722 & 1.01 & 0 & 0.00 & 0.000 & 0.109 & 0.891 & 0.891 \\
\hline \multirow{5}{*}{$\begin{array}{l}\text { Slope angle (in } \\
\text { Degrees) }\end{array}$} & $0-5$ & 21,626 & 3.80 & 45 & 29.80 & 0.577 & 0.138 & 0.285 & 0.862 \\
\hline & $5-10$ & 43,417 & 7.63 & 45 & 29.80 & 0.287 & 0.144 & 0.569 & 0.856 \\
\hline & $10-15$ & 73,134 & 12.86 & 23 & 15.23 & 0.087 & 0.184 & 0.729 & 0.816 \\
\hline & $15-25$ & 203,899 & 35.87 & 25 & 16.55 & 0.034 & 0.246 & 0.720 & 0.754 \\
\hline & $>25$ & 226,352 & 39.82 & 13 & 8.60 & 0.016 & 0.288 & 0.696 & 0.712 \\
\hline \multirow{3}{*}{$\begin{array}{l}\text { Plan Curvature } \\
(100 / \mathrm{m})\end{array}$} & Convex & 231,228 & 40.67 & 23 & 15.23 & 0.116 & 0.469 & 0.414 & 0.531 \\
\hline & Flat & 118,098 & 20.77 & 44 & 29.13 & 0.436 & 0.294 & 0.271 & 0.706 \\
\hline & Concave & 219,102 & 38.54 & 84 & 55.62 & 0.448 & 0.237 & 0.315 & 0.763 \\
\hline \multirow{9}{*}{ TWI } & $1.8-2$ & 72,186 & 12.70 & 3 & 1.99 & 0.007 & 0.123 & 0.869 & 0.877 \\
\hline & $2-3$ & 143,920 & 25.32 & 4 & 2.65 & 0.005 & 0.143 & 0.852 & 0.857 \\
\hline & $3-4$ & 135,369 & 23.81 & 9 & 5.96 & 0.012 & 0.136 & 0.853 & 0.864 \\
\hline & $4-5$ & 95,640 & 16.83 & 28 & 18.54 & 0.051 & 0.108 & 0.841 & 0.892 \\
\hline & $5-6$ & 60,717 & 10.68 & 40 & 26.49 & 0.115 & 0.090 & 0.794 & 0.910 \\
\hline & $6-7$ & 36,029 & 6.34 & 39 & 25.83 & 0.189 & 0.087 & 0.724 & 0.913 \\
\hline & $7-8$ & 17,387 & 3.06 & 18 & 11.92 & 0.181 & 0.100 & 0.719 & 0.900 \\
\hline & $8-10$ & 4945 & 0.87 & 8 & 5.30 & 0.283 & 0.105 & 0.612 & 0.895 \\
\hline & $10-12$ & 2235 & 0.39 & 2 & 1.32 & 0.156 & 0.109 & 0.735 & 0.891 \\
\hline \multirow{9}{*}{ SPI } & $0-10$ & 24 & 0.00 & 0 & 0.00 & 0.000 & 0.115 & 0.885 & 0.885 \\
\hline & $1-50$ & 84 & 0.01 & 0 & 0.00 & 0.000 & 0.115 & 0.885 & 0.885 \\
\hline & 50-100 & 293 & 0.05 & 0 & 0.00 & 0.000 & 0.115 & 0.885 & 0.885 \\
\hline & $100-500$ & 3330 & 0.59 & 0 & 0.00 & 0.000 & 0.116 & 0.884 & 0.884 \\
\hline & 500-1000 & 5494 & 0.97 & 3 & 1.99 & 0.462 & 0.114 & 0.424 & 0.886 \\
\hline & 1000-2000 & 15,970 & 2.81 & 1 & 0.66 & 0.053 & 0.118 & 0.829 & 0.882 \\
\hline & $2000-5000$ & 63,050 & 11.09 & 8 & 5.30 & 0.107 & 0.123 & 0.770 & 0.877 \\
\hline & $5000-10,000$ & 101,088 & 17.78 & 11 & 7.28 & 0.092 & 0.130 & 0.778 & 0.870 \\
\hline & $>10,000$ & 379,095 & 66.69 & 128 & 84.77 & 0.286 & 0.053 & 0.662 & 0.947 \\
\hline \multirow{6}{*}{$\begin{array}{l}\text { Distance from } \\
\text { river }(\mathrm{m})\end{array}$} & $0-500$ & 53,685 & 9.44 & 128 & 84.76 & 0.869 & 0.025 & 0.106 & 0.975 \\
\hline & 500-1000 & 50,645 & 8.90 & 9 & 5.96 & 0.065 & 0.156 & 0.779 & 0.844 \\
\hline & 1000-1500 & 49,097 & 8.63 & 5 & 3.31 & 0.037 & 0.160 & 0.803 & 0.840 \\
\hline & 1500-2000 & 47,719 & 8.39 & 2 & 1.32 & 0.015 & 0.163 & 0.822 & 0.837 \\
\hline & 2000-2500 & 48,645 & 8.55 & 1 & 0.66 & 0.007 & 0.164 & 0.828 & 0.836 \\
\hline & $>2500$ & 318,637 & 56.05 & 6 & 3.97 & 0.007 & 0.331 & 0.662 & 0.669 \\
\hline \multirow{9}{*}{ Rainfall (mm) } & $183-267$ & 2193 & 0.39 & 4 & 2.65 & 0.339 & 0.108 & 0.553 & 0.892 \\
\hline & $267-329$ & 9739 & 1.71 & 26 & 17.22 & 0.497 & 0.093 & 0.410 & 0.907 \\
\hline & $329-375$ & 91,375 & 16.08 & 35 & 23.18 & 0.071 & 0.101 & 0.828 & 0.899 \\
\hline & $375-409$ & 190,890 & 33.58 & 62 & 41.06 & 0.060 & 0.098 & 0.842 & 0.902 \\
\hline & $409-434$ & 170,953 & 30.07 & 19 & 12.58 & 0.021 & 0.138 & 0.841 & 0.862 \\
\hline & $434-468$ & 72,862 & 12.82 & 5 & 3.31 & 0.013 & 0.123 & 0.865 & 0.877 \\
\hline & $468-514$ & 11,300 & 1.99 & 0 & 0.00 & 0.000 & 0.113 & 0.887 & 0.887 \\
\hline & $514-576$ & 12,721 & 2.24 & 0 & 0.00 & 0.000 & 0.113 & 0.887 & 0.887 \\
\hline & $>576$ & 6395 & 1.13 & 0 & 0.00 & 0.000 & 0.112 & 0.888 & 0.888 \\
\hline \multirow{3}{*}{ Lithology } & Cenozoic & 218,690 & 38.47 & 55 & 36.42 & 0.200 & 0.173 & 0.627 & 0.827 \\
\hline & Mesozoic & 317,901 & 55.93 & 87 & 57.62 & 0.218 & 0.161 & 0.621 & 0.839 \\
\hline & Paleozoic & 26,641 & 4.69 & 9 & 5.96 & 0.269 & 0.165 & 0.566 & 0.835 \\
\hline
\end{tabular}


Table 3. Cont.

\begin{tabular}{cccccccccc}
\hline Factor & Class & $\begin{array}{c}\text { No. of Pixels } \\
\text { in Domain }\end{array}$ & $\begin{array}{c}\text { Percentage } \\
\text { of Domain }\end{array}$ & $\begin{array}{c}\text { No. of } \\
\text { Floods }\end{array}$ & $\begin{array}{c}\text { Percentage } \\
\text { of Floods }\end{array}$ & Bel & Dis & Unc & Pls \\
\hline \multirow{5}{*}{ Land use } & Rangeland & 52 & 2.40 & 132 & 87.42 & 0.016 & 0.210 & 0.773 & 0.790 \\
& Bare land & 526,843 & 92.68 & 9 & 5.96 & 0.144 & 0.116 & 0.740 & 0.884 \\
& forest & 4043 & 0.71 & 5 & 3.31 & 0.010 & 0.126 & 0.865 & 0.874 \\
& Garden & 33,421 & 5.88 & 0 & 0.00 & 0.138 & 0.122 & 0.739 & 0.878 \\
& residential & 759 & 0.13 & 1 & 0.66 & 0.049 & 0.122 & 0.829 & 0.878 \\
& irrigation & 1312 & 0.23 & 0 & 0.00 & 0.000 & 0.123 & 0.877 & 0.877 \\
& water body & 2004 & 0.35 & 4 & 2.65 & 0.664 & 0.119 & 0.216 & 0.881 \\
\hline & $-0.69--0.35$ & 5057 & 0.89 & 5 & 3.31 & 0.199 & 0.096 & 0.705 & 0.904 \\
& $-0.34--0.18$ & 11,625 & 2.05 & 7 & 4.64 & 0.121 & 0.096 & 0.783 & 0.904 \\
& $-0.17--0.13$ & 28,452 & 5.01 & 17 & 11.26 & 0.120 & 0.092 & 0.788 & 0.908 \\
& $-0.12--0.08$ & 188,356 & 33.14 & 15 & 9.93 & 0.016 & 0.133 & 0.851 & 0.867 \\
& $-0.07--0.03$ & 177,441 & 31.22 & 32 & 21.19 & 0.036 & 0.113 & 0.851 & 0.887 \\
& $-0.02-0.05$ & 27,652 & 4.86 & 22 & 14.57 & 0.160 & 0.089 & 0.751 & 0.911 \\
& $0.06-0.18$ & 26,985 & 4.75 & 15 & 9.93 & 0.112 & 0.093 & 0.795 & 0.907 \\
& $0.19-0.33$ & 28,897 & 5.08 & 20 & 13.25 & 0.139 & 0.090 & 0.770 & 0.910 \\
& $0.34-0.47$ & 38,542 & 6.78 & 16 & 10.60 & 0.084 & 0.095 & 0.822 & 0.905 \\
& $0.48-0.73$ & 35,421 & 6.23 & 2 & 1.32 & 0.011 & 0.104 & 0.885 & 0.896 \\
\hline
\end{tabular}

The TWI factor had a positive correlation with flood occurrence, indicating a higher probability of flooding. The effect of SPI classes on the probability of flooding was also studied. A proportional relationship between SPI value and the number of recorded flood points was observed indicating that a higher SPI value increases the possibility of flooding. The highest flooding probability was found to be related to the 500 to 1000 class. Distance from the river was also an important factor in mapping areas vulnerable to flooding [13]. Results indicated that areas farther away from the river have a lower risk of flooding; in fact, $85 \%$ of the flood events were placed in the first class or within $0-500 \mathrm{~m}$ of the river (the Bel value was equal to 0.869 ). According to the EBF method, the highest possibility of a flood occurrence was related to the 267-329 mm class of rainfall. The geology of the study catchment consists of three classes (Mesozoic, Cenozoic, and Paleozoic Eras). Almost 57\%, 37\%, and 6\% of floods were found to occur in Mesozoic, Cenozoic, and Paleozoic, respectively.

With regard to the relationship between the land-use map and the position of the recorded flood points, $87.5 \%$ of flooding points were placed in rangeland areas, with no recorded flood points in the garden and irrigation land-use types. In terms of NDVI, the results indicated that there was no correlation observed between the EBF values and the NDVI classes. The highest and lowest probabilities of flood occurrence, however, were found to be related to NDVI ranging from -0.69 to -0.35 and 0.48 to 0.73 , respectively.

\subsection{Multicollinearity Diagnosis}

According to Table 4, the smallest tolerance and the largest VIF were 0.300 and 3.331, respectively, indicating that there was no multicollinearity between independent factors in the study area.

Maps related to the four parameters of the EBF model are shown in Figure 5. The Bel map (Figure 5a) shows the distribution of flood occurrences. The Bel map was compared to the Dis map (Figure 5b), which showed areas with a higher Bel value had a lower Dis, and vice versa, indicating that areas with higher susceptibilities to flooding are characterized by a high degree of belief and a low degree of disbelief for each event. According to Pourghasemi and Beheshtirad [65], detailed information cannot be extracted from the Unc map (Figure 5c). However, areas with a higher Bel and thus a higher susceptibility to flooding were represented by the lowest values of Unc. The Pls map was very similar to the Bel map, with the difference being that the contrast between the low and high degrees was less evident in the Pls map (Figure 5d). 
Table 4. The B coefficients and multicollinearity diagnosis indices for independent variables in the LR model.

\begin{tabular}{|c|c|c|c|c|c|c|c|}
\hline \multirow[t]{2}{*}{ Model } & \multicolumn{2}{|c|}{$\begin{array}{l}\text { Unstandardized } \\
\text { Coefficients }\end{array}$} & \multirow{2}{*}{$\frac{\begin{array}{l}\text { Standardized } \\
\text { Coefficients }\end{array}}{\text { Beta }}$} & \multirow[t]{2}{*}{$\mathbf{t}$} & \multirow[t]{2}{*}{ Sig. } & \multicolumn{2}{|c|}{ Collinearity Statistics } \\
\hline & B & SE & & & & Tolerance & VIF \\
\hline Constant & 0.130 & 0.191 & & 0.679 & 0.489 & & \\
\hline Altitude (m) & 0.00 & 0.00 & -0.300 & -6.030 & 0.00 & 0.300 & 3.331 \\
\hline Slope angle (in Degrees) & -0.005 & 0.002 & -0.125 & -2.731 & 0.007 & 0.353 & 2.833 \\
\hline Plan curvature (100/m) & -0.074 & 0.028 & -0.082 & -2.691 & 0.008 & 0.806 & 1.240 \\
\hline TWI & 0.191 & 0.026 & 0.346 & 7.324 & 0.00 & 0.332 & 3.016 \\
\hline SPI & $-5.612 \times 10^{-8}$ & 0.00 & -0.025 & -0.799 & 0.425 & 0.774 & 1.293 \\
\hline Distance from river (m) & 0.00 & 0.00 & -0.321 & -7.228 & 0.00 & 0.377 & 2.656 \\
\hline Rainfall (mm) & 0.00 & 0.00 & 0.023 & 0.716 & 0.474 & 0.714 & 1.401 \\
\hline Lithology & 0.002 & 0.01 & 0.047 & 1.612 & 0.108 & 0.876 & 1.142 \\
\hline Land use & -0.004 & 0.012 & -0.011 & -0.349 & 0.727 & 0.784 & 1.275 \\
\hline NDVI & 0.105 & 0.086 & 0.038 & 1.218 & 0.224 & 0.779 & 1.284 \\
\hline
\end{tabular}

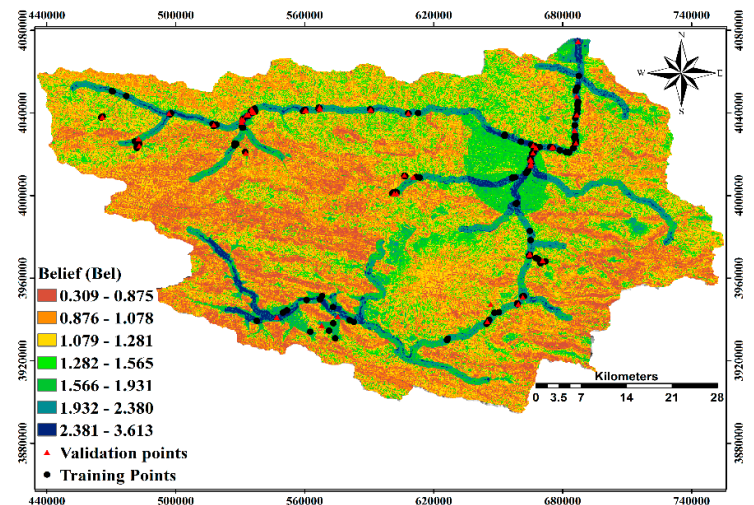

(a)

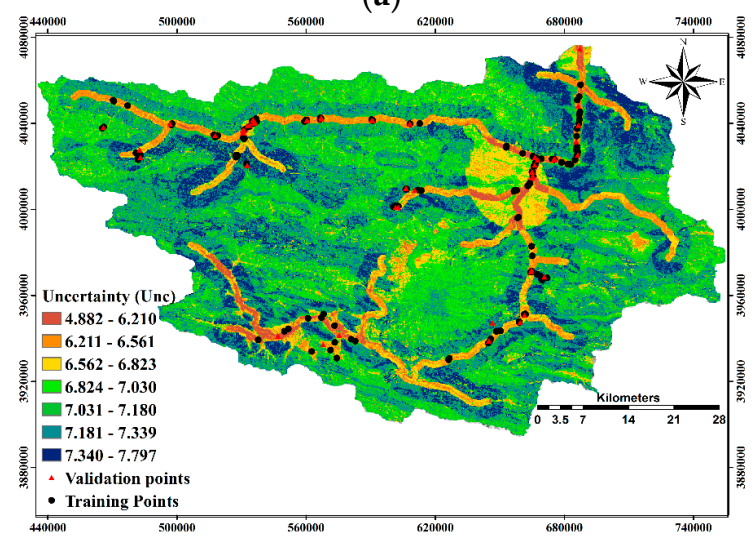

(c)

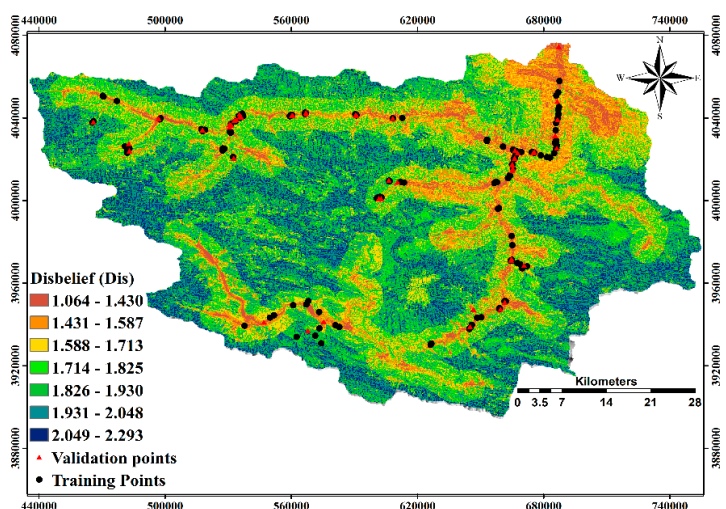

(b)

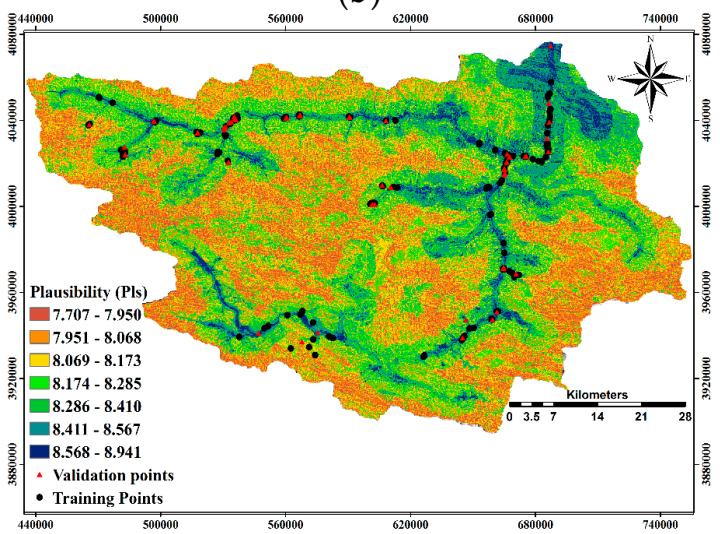

(d)

Figure 5. Integrated results of EBF model: (a) belief (Bel), (b) disbelief (Dis), (c) uncertainty (Unc), (d) plausibility (Pls).

The Flood Susceptibility Map (FSM) was implemented using the EBF model (Figure 6a) through Equation (14):

$F S M=\left(\right.$ altitude $\left._{B e l}\right)+\left(\right.$ slope $\left._{B e l}\right)+\left(\right.$ curvature $\left._{B e l}\right)+\left(\mathrm{TWI}_{B e l}\right)+\left(\mathrm{SPI}_{B e l}\right)+\left(\right.$ distance from river $\left._{B e l}\right)+$ $\left(\right.$ rainfall $\left._{B e l}\right)+\left(\right.$ lithology $\left._{B e l}\right)+\left(\right.$ landuse $\left._{B e l}\right)+\left(\mathrm{NDVI}_{B e l}\right)$ 


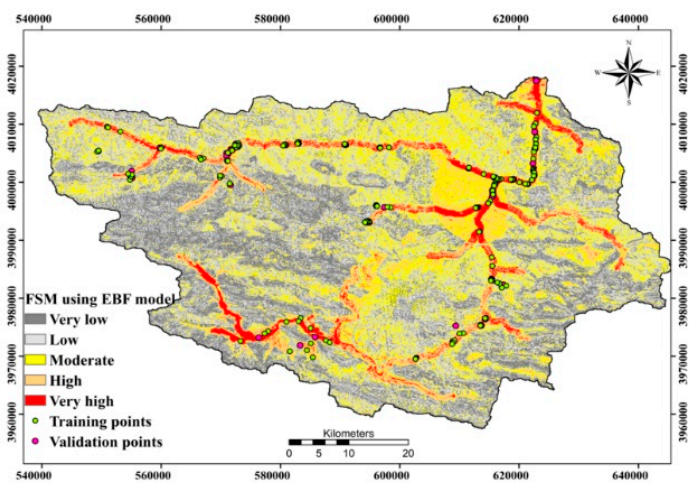

(a)

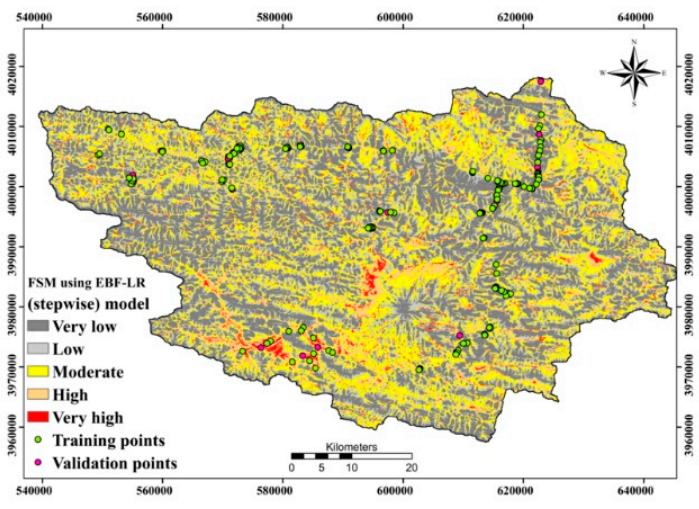

(c)

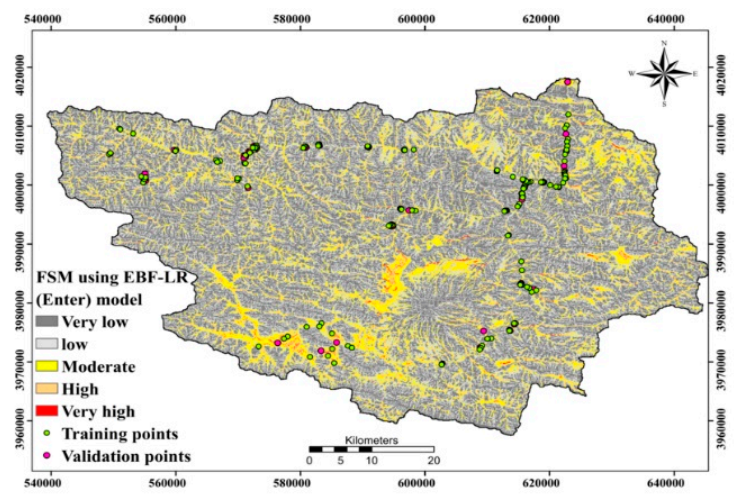

(b)

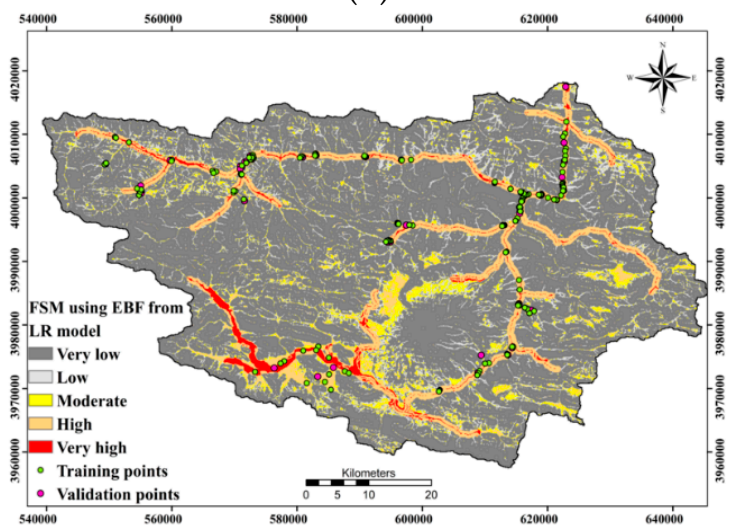

(d)

Figure 6. Flood Susceptibility Index using (a) EBF, (b) EBF-LR (Enter), (c) EBF-LR (Stepwise), (d) EBF from LR.

\subsection{Flood Susceptibility Mapping Using LR Model}

In this study, the "enter" and "stepwise" methods were used in an LR model. In the enter method, ten conditioning factors were assumed; altitude, slope angle, plan curvature, TWI, SPI, distance from river, rainfall, lithology, land-use, and NDVI, with coefficients of $-0.004,-0.162,-0.638,3.32,0.00$, $0.002,-0.003,0.10,-0.362$, and -0.453 , respectively. In the stepwise method, the conditioning factors that had a significant impact on flooding were selected automatically by adding or removing variables in a certain order in the SPSS software; these factors were slope angle, distance from river, altitude, and TWI with coefficients of $-0.141,-0.002,-0.004$, and 3.402, and degrees of significance of 0.021 , $0.00,0.00$, and 0.00 , respectively (Table 5). Negative weight values for LR coefficients indicate that the flooding events are negatively related to the independent variables [73]. After running the LR model and obtaining the coefficients, each coefficient was multiplied by the corresponding conditioning factor in order to find the z-value, as shown below in Equations (15) and (16):

$$
\begin{aligned}
& Z(\text { enter })=(-0.004 \text { altitude })+(-0.162 \text { slope })+(-0.638 \text { curvature })+(3.32 \text { TWI })+ \\
& (0 \text { SPI })+(0.002 \text { distance from river })+(-0.003 \text { rainfall })+(0.1 \text { lithology })+ \\
& (-0.362 \text { landuse })+(-0.453 \mathrm{NDVI})+1.02
\end{aligned}
$$

$Z$ (stepwise $)=(-0.004$ altitude $)+(-0.141$ slope $)+(3.402$ TWI $)+$

$(-0.002$ distance from river $)-2.19$ 
Table 5. Conditioning factor coefficients for the enter and stepwise LR methods.

\begin{tabular}{ccc}
\hline Method & Factors & B \\
\hline & Altitude $(\mathrm{m})$ & -0.004 \\
& Slope angle & -0.162 \\
& Plan curvature $(100 / \mathrm{m})$ & -0.638 \\
& TWI & 3.320 \\
Enter & SPI & 0.00 \\
& Distance from river(m) & 0.002 \\
& Rainfall (mm) & -0.003 \\
& Lithology & 0.10 \\
& Land use & -0.362 \\
& NDVI & -0.453 \\
& Constant & 1.025 \\
\hline \multirow{2}{*}{ Forward (Stepwise) } & Altitude (m) & -0.004 \\
& Slope & -0.141 \\
& TWI & 3.402 \\
& Distance from river (m) & -0.002 \\
& Constant & -2.196 \\
\hline
\end{tabular}

\subsection{Flood Susceptibility Mapping Using EBF-LR and EBF from LR Model}

The results of the LR model (stepwise) showed that slope, distance from the river, altitude and TWI (with significance values equal to $0.021,0.00,0.00$ and 0.00 , respectively) were the most important factors influencing flood occurrence. The difference in -2log likelihood (-2LL) was used as an indicator of the effectiveness of improving on the null model (Table 6). Nagelkerke's and Cox/Snell's R-squared tests were used to measure the model's efficacy, with a better model having a higher Nagelkerke's and Cox/Snell's R-squared value [21]. Finally, Equations (17)-(21) for the EBF-LR (enter and stepwise) hybrid model were entered into the raster calculator of ArcGIS 10.1 and implemented as follows (Figure 6b-c):

$$
\begin{aligned}
& \mathrm{Z}(\mathrm{EBF}-\mathrm{LR} . \text { Enter })=\left(-0.004 \text { altitude }_{\mathrm{EBF}}\right)+\left(-0.162 \text { slope }_{\mathrm{EBFl}}\right)+\left(-0.63 \text { curvature }_{\mathrm{EBFl}}\right)+\left(3.32 \mathrm{TWI}_{\mathrm{EBFl}}\right)+ \\
& \left(\mathrm{OSPI}_{\mathrm{EBFl}}\right)+\left(0.002 \text { dis tan ce from river } \mathrm{EBFl}_{\mathrm{EBI}}\right)+(-0.003 \text { rainfall } \mathrm{EBFl})+\left(0.1 \text { litho } \log \mathrm{y}_{\mathrm{EBFl}}\right) \\
& +\left(-0.362 \text { landuse }_{\mathrm{EBF}}\right)+\left(-0.45 \mathrm{NDVI}_{\mathrm{EBFl}}\right)+1.025 \\
& \mathrm{Z}(\mathrm{EBF}-\mathrm{LR} . \text { Stepwise })=\left(-0.004 \text { altitude }_{\mathrm{EBF}}\right)+\left(-0.141 \text { slope }_{\mathrm{EBFl}}\right)+\left(3.402 \mathrm{TWI}_{\mathrm{EBFl}}\right)+ \\
& \left(-0.002 \text { distance from } \text { river }_{\mathrm{EBFl}}\right)-2.196 \\
& \operatorname{FSM}(\text { EBF }- \text { LR.enter })=P=\frac{\mathrm{e}^{\mathrm{z}(\text { EBF-LR.enter })}}{1+\mathrm{e}^{\mathrm{z}(\text { EBF-LR.enter })}} \\
& \text { FSM }(\text { EBF }- \text { LR.stepwise })=P=\frac{\mathrm{e}^{\mathrm{Z} \text { (EBF-LR.stepwise })}}{1+\mathrm{e}^{\mathrm{Z}(\text { EBF-LR.stepwise })}}
\end{aligned}
$$

Table 6. LR model summary.

\begin{tabular}{ccccc}
\hline Methods & Step & $\mathbf{- 2}$ Log Likelihood & Cox and Snell's R Squared & Nagelkerke's R Squared \\
\hline Enter & 1 & $42.604^{\mathrm{a} 1}$ & 0.712 & 0.949 \\
\hline & 1 & $198.454^{\mathrm{a}}$ & 0.518 & 0.690 \\
Forward & 2 & $83.501^{\mathrm{b}}$ & 0.670 & 0.894 \\
(Stepwise) & 3 & $53.481^{\mathrm{c}}$ & 0.702 & 0.935 \\
& 4 & $47.401^{\mathrm{c}}$ & 0.708 & 0.943 \\
\hline
\end{tabular}

a1. Estimation terminated at iteration number 10 because parameter estimates changed by less than 0.001 . a2. Estimation terminated at iteration number 6 because parameter estimates changed by less than $0.001 \mathrm{~b}$. Estimation terminated at iteration number 8 because parameter estimates changed by less than 0.001 . c. Estimation terminated at iteration number 9 because parameter estimates changed by less than 0.001 . 
Based on the four factors affecting flooding obtained by the LR stepwise model, the EBF model was re-run, and the final map was produced, which is shown in Figure 6d. Parameters with no significant values were deleted from the EBF model. The result is shown in Equation (21) below:

$$
F S M(\text { EBF from LR })=\left(\text { altitude }_{\mathrm{Bel}}\right)+\left(\text { slope }_{\mathrm{Bel}}\right)+\left(\text { distance from river }_{\mathrm{Bel}}\right)+\left(\mathrm{TWI}_{\mathrm{Bel}}\right)
$$

\subsection{Validation of the Flood Susceptibility Maps and Their Comparison}

Figure 7a-b shows the success-rate and prediction rate curves for the four FSMs. As can be seen, the EBF model has the largest AUC (94.61\%), and the EBF-LR (stepwise) model has the lowest AUC $(56.31 \%)$. As the training points of the model were used for the creation of the success-rate curve, this approach may not be appropriate for assessing the predictive ability of the model $[19,92,93]$. AUC for the prediction-rate curve indicates how well the model predicts the flood $[91,94,95]$. The prediction rate was evaluated using the $30 \%$ of points that were not used in the models' training phases (i.e., the $30 \%$ used for model validation) as this method shows the predictive capability of the model [96]. The AUC of the prediction-rate curves for models of EBF, EBF from LR, EBF-LR (Enter), and EBF-LR (Stepwise) were $94.55,66.41,83.19$, and 52.98\%, respectively. For example, the AUC of 0.9455 , which is for the EBF model, shows a predicting accuracy of $94.55 \%$; hence, the most accurate prediction of the flood susceptibility map was the EBF model. Conversely, the lowest predictive accuracy was related to the EBF-LR (Stepwise). Ultimately, the EBF, EBF from LR, and EBF-LR (Enter) models displayed acceptable accuracy in predicting the final map.

\subsection{Comparison of Class's Percent of Different Models}

Based on the results from the four implemented models, the final flood susceptibility maps were prepared and categorized into very low, low, moderate, high, and very high susceptibility classes (Figure 8). The EBF model was chosen as a basis for model comparison since it showed the highest accuracy among the studied models. According to the EBF model, the breakdown of susceptibility classes in the study area were $23.7 \%$ (very low), 38.7\% (low), 23.04\% (moderate), 9.88\% (high), and $4.67 \%$ (very high). The susceptibility class percentages for the EBF-LR (Enter) were 43.67\%, 30.68\%, $18.17 \%, 7.28 \%$, and $0.21 \%$, for EBF-LR (Stepwise) were $38.93 \%, 22.85 \%, 26.68 \%, 10.38 \%, 1.17 \%$, and for EBF from LR were $72.37 \%, 10.68 \%, 5 \%, 9.95 \%$ and $2 \%$, respectively. The results show that the implemented models of EBF-LR (Enter), EBF-LR (Stepwise), and EBF from LR overestimated the area in the very low class while underestimating the area in the low susceptibility class when compared to the outputs of the EBF model. All four models roughly estimated an equal percent of the area in the high susceptibility class category. Alternatively, the EBF-LR (Enter), EBF-LR (Stepwise), and EBF from LR models displayed lower values for the very high susceptibility class when compared with the EBF model, although all four models did exhibit comparatively small values in this class. 

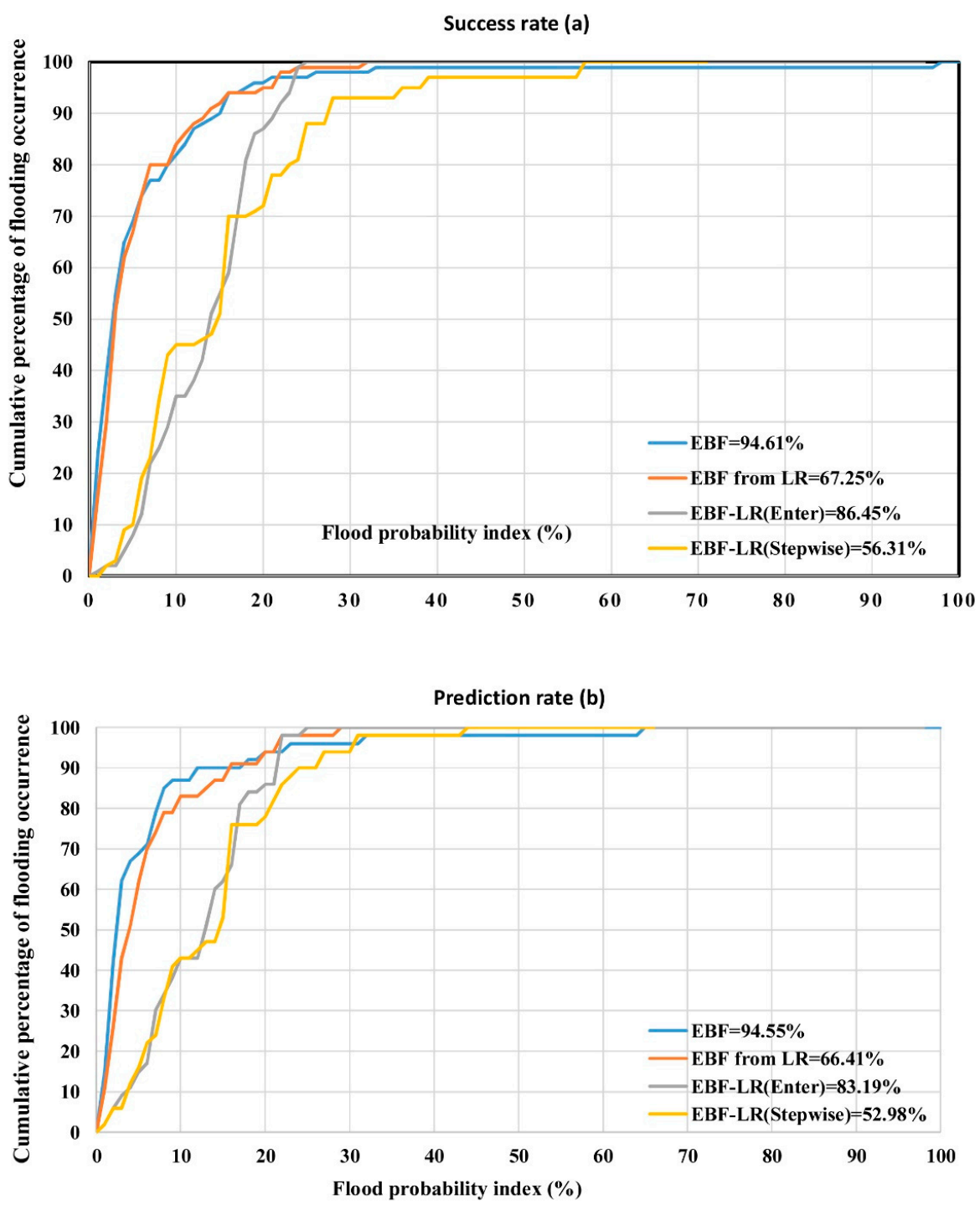

Figure 7. The success and prediction-rate curves for flooding map; (a) success rate and (b) prediction rate.

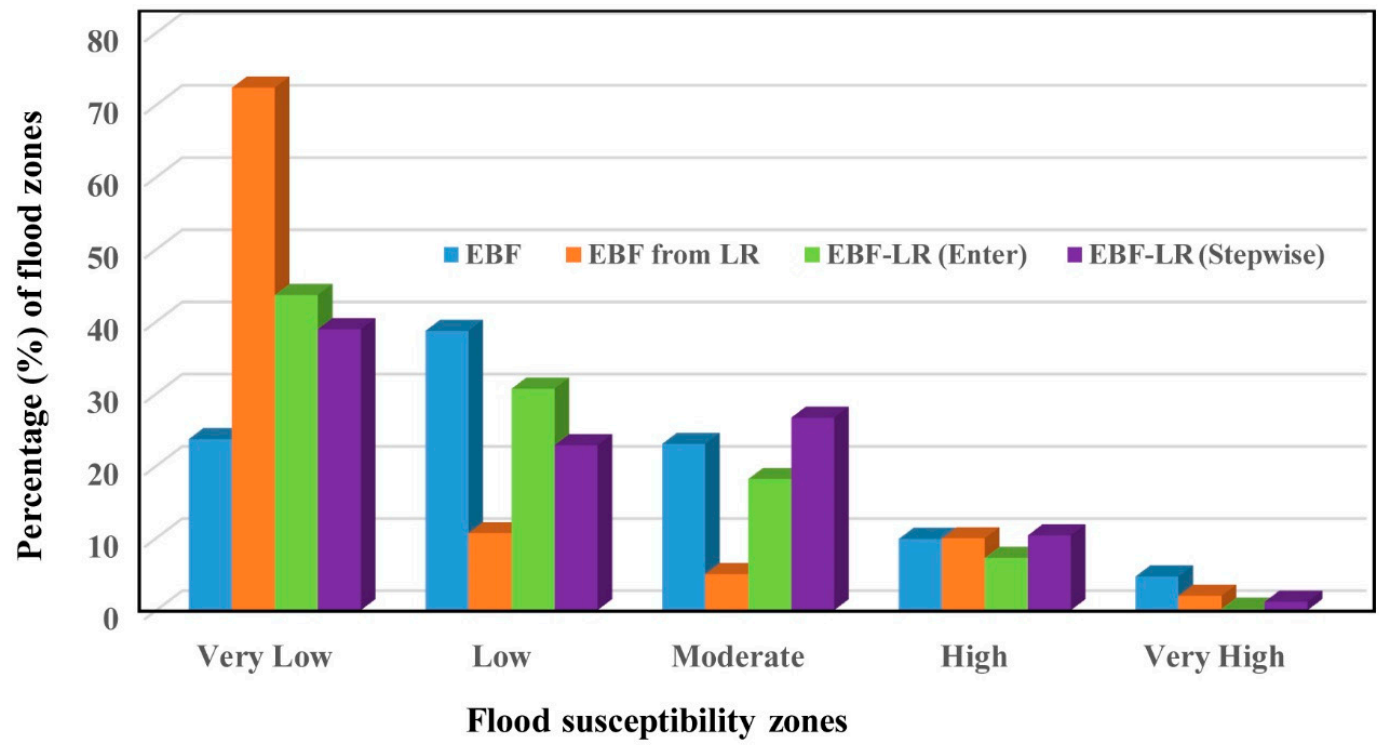

Figure 8. A histogram showing the percentage of flood zones that fall into the various classes from the four models. 


\section{Discussion}

Analysis of elevation maps, as well as the position of flood points, revealed that flooding usually occurs at lower elevations. It also indicated that the frequency of recorded flooding events decreased as elevation class increased, as floods generally occur in flat, lower elevation and lower slope areas where water can coalesce. Additionally, as TWI shows wetness, meaning areas with a high TWI have saturated soil, the flood potential is higher with greater TWI values. In particular, the river and its surrounding areas maintain higher flood susceptibility than any other region, and the flood risk was shown to be reduced by increasing the distance from the river. Furthermore, rainfall depth and EBF values showed an inverse relationship; this may be because rainfall often increases at higher altitudes, although the risk of flooding significantly decreases. Overall, these results are in accordance with the results of Khosravi et al. [6,16] and Tien Bui et al. [63].

The relationship between the flood locations and lithological map depicted that least amount of flooding occurred in the areas with high permeability formations (31.062\%). These formations had a high potential for saturating processes and hence allowed more infiltration than the low $(37.568 \%)$ and moderate $(31.369 \%)$ permeability formations with all other factors constant. The regions with volcanic rocks and low permeability allow more runoff to be transferred into streams, creating conditions where overbank can occur $[23,97]$. On the other hand, streams both collect water from runoff generated upland adjacent to the streams and from rainfall falling directly on them. Therefore, streams have been more susceptible to flooding in the Haraz catchment.

In terms of land use, villages close to the Haraz River, agricultural areas, such as citrus gardens, and areas with low topographic gradients are more susceptible to flooding. The results showed that most points recorded in the rangeland are close to registered residential areas and gardens; therefore, a single flood event may turn into a fatal natural hazard, causing catastrophic financial damage as well as claiming many human lives. Such devastation has been one of the leading causes of death and economic distress in the Haraz catchment, according to annual reports by authorities.

According to Park [82], the main limitation of the EBF method is that if a flood event did not happen in a represented class, the Bel and Dis results would be equal to zero, meaning that by Equation (10) the Unc or uncertainty values would be equal to 1 . Walley [98] stated that if the models were provided with complete information about the study area, Pls-Bel would be expected to be equal to zero (in this case Bel is called Bayesian belief function), confirming that the two maps of Bel and Pls should have similar results [18]; which they did in this study. Furthermore, the results of this study were also consistent with other research $[19,21,99,100]$. According to the results of Nampak et al. [19], the main advantage of the Dempster-Shafer theory is that the application of an EBF model not only provides predictive maps of the desired area but also provides the predictive degree of uncertainty. The results of the present study were also consistent with Razavi and Malek [101], as they compared the results of the EBF method with an ensemble of AHP and EBF, finding that that EBF model has a higher prediction power than the ensemble method. Tehrany and Kumar [102] used an EBF model for flood susceptibility and compared the results with LR and FR models, similarly finding that the EBF model yielded the highest prediction power. Similarly, Arabameri at al. [28] found that EBF model had the highest prediction power over FR, TOPSIS, and VIKOR models. In contrast, Khosravi et al. [16], who applied FR and WOE models to a similar case study with similar input data, found that the FR and WOE models had slightly better prediction powers than the EBF model and its ensembles.

The current study showed that a greater number of input variables enhanced the results of modeling, which corresponded to Donati and Turrini [103], who explained that a higher number of variables would likely result in improved model accuracy. The high accuracy of the EBF model used in this study was in line with Nampak et al. [19], Pourghasemi and Beheshtirad [65], and Rahmati et al. [17]. Additionally, the developed FSMs showed that the areas nearest to the Haraz River with low slope, flat curvature, low altitude, and a high TWI were highly susceptible to flooding, which is in agreement with Tehrany et al. [13] and Khosravi et al. [6,16]. Overall, the results of the current study could be extremely useful in improving flood management and planning within the area in 
order to prevent and mitigate further damages due to flooding hazards. For example, by avoiding the construction of homes, villas, or industries in susceptible zones, and by employing both structural and non-structural approaches for future flood mitigation, the enduring damage and devastation caused by floods can be significantly reduced.

One of the main limitations of the current study was the use of Google Earth, rather than a field survey, for the identification of non-flooding points, though some prior researchers that had done the same, such as Tehrany et al. [15,64], Khosravi et al. [16] and Khosravi et al. [27]. Additionally, LIDAR DEM, with its high resolution, would have likely affected the results and prediction power of the models positively; thus, it is recommended that further studies employ LIDAR instead of ASTER GDEM. Further recommendations for future research include a comprehensive comparative study involving an assessment of the accuracy and simplicity of assorted bivariate, multivariate, machine learning, data mining, and multi-criteria decision-making models and their ensembles, for improving flood prediction.

Furthermore, as the current case study was in a region with diverse topography, it is recommended that future researchers examine the models' prediction power in mountainous areas and flat areas separately, to determine which model is better for which type of topography. The main limitation of the current methodology is that the models used resulted in flood susceptibility maps (prone areas without depth, velocity, and hydraulic details) which differ from the results of 2D flood inundation models [97]. Therefore, it is recommended that future researchers compare the results of the present study with the $2 \mathrm{D}$ results of numerical models such as HEC-RAS. However, it should be noted that in comparison to susceptibility mapping, 1D and 2D hydraulic models are mostly performed on short river sections but not limited to any short reach and can be used for a catchment with a complicated drainage network. It is important to bear in mind that hydraulic models require different input data (e.g., design discharges with different return period, river cross sections, and roughness coefficients in main channel and flood plains) and better accuracy (e.g., high-resolution DEM and detailed topography). Therefore, combining the results of both flood inundation and susceptibility maps may offer a better outcome for decision makers in flood mitigation and management.

\section{Conclusions}

The main goal of this study was to assess the performance of an EBF model that is rarely used for the development of flood susceptibility maps, in comparison to an LR model and an ensemble LR EBF model, in creating FSMs for the Haraz Catchment, Iran. The LR model was implemented using independent variables that were weighted and reclassified by the EBF model. Based on the coefficients obtained from the LR model, the TWI parameter had the highest weight and thus the greatest impact on flood occurrence. The relationship between factors affecting flooding and the final maps generated by the models indicated that most flooding events occur in areas where the topography is relatively flat. The FSMs created in the current study illustrated that most flooding in the Haraz Catchment occurs in areas directly adjacent to the river, which are often characterized by low slope, and concave or flat curvature. Due to the steep, mountainous areas in the Haraz Catchment, frequent rapid runoff occurs, and water flows down toward the Haraz River, causing flash flooding in areas where topography permits. This is important as most residential and agricultural zones within this catchment are located in flat areas with low slopes, and thus were found to be especially susceptible to flooding.

According to the success-rate and prediction-rate curves, the EBF model exhibited the highest accuracy with a $94.61 \%$ success rate and $94.5 \%$ prediction rate. Alternatively, the developed EBF from LR model had an accuracy of $66.41 \%$, which was $28.5 \%$ lower than the EBF model alone. Based on the expressed curves, the accuracy of the EBF-LR enter and stepwise models were found to be $83.19 \%$ and $52.98 \%$, respectively; with the difference between these two models being $30.21 \%$. The lowest accuracy belonged to the EBF-LR (stepwise) model, indicating this method is inappropriate for determining flood-prone areas. Furthermore, the results of the EBF-LR (stepwise) model suggested that altitude, slope, TWI, and distance from the river, may not be sufficient to adequately validate the model for flood 
susceptibility prediction. This is likely because the occurrence of a natural hazard, like flooding, is very complex and cannot be predicted with high accuracy when limited parameters are being considered in model development.

Furthermore, according to the FSM resulting from the EBF model, $15 \%$ of the total area was located in the high and very high susceptibility classes while $62 \%$ of the area was located within the low and very low susceptibility classes. Therefore, it is recommended that researchers and stakeholders identify flood-prone areas in additional catchments using the EBF model, which has a high degree of accuracy and relative simplicity. Finally, the results of this research also indicated that the impact of the different classes of the factors was more important for natural hazard assessment and mapping than the impact of the different factors themselves (i.e., the weights of the individual layers).

The developed model can now be used as a tool for decision making by management agencies such as the Department of Water and Natural Resources. The results and insights gained from this modeling effort can provide an improved understanding of flood susceptibility in the region. More generally, the results can help to improve the identification of flood-prone regions in other areas of the world. Overall, flood susceptibility mapping is essential for the prevention and mitigation of damages resulting from future floods, specifically in the northern areas of Iran. In future studies, it is recommended that researchers focus on the flood-prone areas identified in order to develop best management practices and implement structural and non-structural methods for potential damage reduction.

Author Contributions: D.T.B., K.K., H.S., P.D., J.F.A., M.M., B.T.P., H.R.P., M.M., S.B., B.P., A.S., K.C., and S.L. contributed equally to the work. K.K., H.S., and A.S. collected field data and conducted the flood susceptibility mapping and analysis. D.T.B., K.K., H.S., H.R.P., M.M., S.B., A.S., and K.C. wrote the manuscript. D.T.B., P.D., J.F.A., M.M., B.T.P., B.P., and S.L. provided critical comments in planning this paper and edited the manuscript. All the authors discussed the results and edited the manuscript.

Funding: This research was financial supported by the Iran National Science Foundation (INSF) through research project no. 96004000, and through the Basic Research Project of the Korea Institute of Geoscience, Mineral Resources (KIGAM) funded by the Minister of Science and the ICT.

Acknowledgments: In this section you can acknowledge any support given which is not covered by the author contribution or funding sections. This may include administrative and technical support, or donations in kind (e.g., materials used for experiments).

Conflicts of Interest: The authors declare no conflict of interest.

\section{References}

1. Youssef, A.M.; Pradhan, B.; Hassan, A.M. Flash flood risk estimation along the st. Katherine road, southern sinai, Egypt using GIS based morphometry and satellite imagery. Environ. Earth Sci. 2011, 62, 611-623. [CrossRef]

2. Grahn, T.; Nyberg, L. Assessment of pluvial flood exposure and vulnerability of residential areas. Int. J. Disaster Risk Reduct. 2017, 21,367-375. [CrossRef]

3. Chapi, K.; Singh, V.P.; Shirzadi, A.; Shahabi, H.; Bui, D.T.; Pham, B.T.; Khosravi, K. A novel hybrid artificial intelligence approach for flood susceptibility assessment. Environ. Model. Softw. 2017, 95, 229-245. [CrossRef]

4. Bubeck, P.; Botzen, W.J.; Aerts, J.C. A review of risk perceptions and other factors that influence flood mitigation behavior. Risk Anal. Int. J. 2012, 32, 1481-1495. [CrossRef] [PubMed]

5. Shafizadeh-Moghadam, H.; Valavi, R.; Shahabi, H.; Chapi, K.; Shirzadi, A. Novel forecasting approaches using combination of machine learning and statistical models for flood susceptibility mapping. J. Environ. Manag. 2018, 217, 1-11. [CrossRef]

6. Khosravi, K.; Pham, B.T.; Chapi, K.; Shirzadi, A.; Shahabi, H.; Revhaug, I.; Prakash, I.; Bui, D.T. A comparative assessment of decision trees algorithms for flash flood susceptibility modeling at Haraz watershed, Northern Iran. Sci. Total Environ. 2018, 627, 744-755. [CrossRef]

7. Opolot, E. Application of remote sensing and geographical information systems in flood management: A review. Res. J. Appl. Sci. Eng. Technol. 2013, 6, 1884-1894. [CrossRef]

8. Varoonchotikul, P. Flood Forecasting Using Artificial Neural Networks; CRC Press: Boca Raton, FL, USA, 2003. 
9. Levy, J.K.; Hartmann, J.; Li, K.W.; An, Y.; Asgary, A. Multi-criteria decision support systems for flood hazard mitigation and emergency response in urban watersheds 1. JAWRA J. Am. Water Resour. Assoc. 2007, 43, 346-358. [CrossRef]

10. Lee, J.-M.; Hyun, K.-H.; Choi, J.-S.; Yoon, Y.-J.; Geronimo, F.K.F. Flood reduction analysis on watershed of lid design demonstration district using swmm5. Desalin. Water Treat. 2012, 38, 255-261. [CrossRef]

11. Oh, H.-J.; Pradhan, B. Application of a neuro-fuzzy model to landslide-susceptibility mapping for shallow landslides in a tropical hilly area. Comput. Geosci. 2011, 37, 1264-1276. [CrossRef]

12. Tien Bui, D.; Shahabi, H.; Shirzadi, A.; Chapi, K.; Alizadeh, M.; Chen, W.; Mohammadi, A.; Ahmad, B.; Panahi, M.; Hong, H. Landslide detection and susceptibility mapping by AIRSAR data using support vector machine and index of entropy models in Cameron Highlands, Malaysia. Remote Sens. 2018, 10, 1527. [CrossRef]

13. Tehrany, M.S.; Pradhan, B.; Jebur, M.N. Spatial prediction of flood susceptible areas using rule based decision tree $(\mathrm{dt})$ and a novel ensemble bivariate and multivariate statistical models in GIS. J. Hydrol. 2013, 504, 69-79. [CrossRef]

14. Tehrany, M.S.; Pradhan, B.; Mansor, S.; Ahmad, N. Flood susceptibility assessment using GIS-based support vector machine model with different kernel types. Catena 2015, 125, 91-101. [CrossRef]

15. Tehrany, M.S.; Pradhan, B.; Jebur, M.N. Flood susceptibility analysis and its verification using a novel ensemble support vector machine and frequency ratio method. Stoch. Environ. Res. Risk Assess. 2015, 29, 1149-1165. [CrossRef]

16. Khosravi, K.; Nohani, E.; Maroufinia, E.; Pourghasemi, H.R. A gis-based flood susceptibility assessment and its mapping in Iran: A comparison between frequency ratio and weights-of-evidence bivariate statistical models with multi-criteria decision-making technique. Nat. Hazards 2016, 83, 947-987. [CrossRef]

17. Rahmati, O.; Pourghasemi, H.R.; Zeinivand, H. Flood susceptibility mapping using frequency ratio and weights-of-evidence models in the Golastan Province, Iran. Geocarto Int. 2016, 31, 42-70. [CrossRef]

18. Althuwaynee, O.F.; Pradhan, B.; Lee, S. Application of an evidential belief function model in landslide susceptibility mapping. Comput. Geosci. 2012, 44, 120-135. [CrossRef]

19. Nampak, H.; Pradhan, B.; Manap, M.A. Application of GIS based data driven evidential belief function model to predict groundwater potential zonation. J. Hydrol. 2014, 513, 283-300. [CrossRef]

20. Tien Bui, D.; Shahabi, H.; Shirzadi, A.; Chapi, K.; Hoang, N.-D.; Pham, B.; Bui, Q.-T.; Tran, C.-T.; Panahi, M.; Bin Ahamd, B. A novel integrated approach of relevance vector machine optimized by imperialist competitive algorithm for spatial modeling of shallow landslides. Remote Sens. 2018, 10, 1538. [CrossRef]

21. Althuwaynee, O.F.; Pradhan, B.; Park, H.-J.; Lee, J.H. A novel ensemble bivariate statistical evidential belief function with knowledge-based analytical hierarchy process and multivariate statistical logistic regression for landslide susceptibility mapping. Catena 2014, 114, 21-36. [CrossRef]

22. Pradhan, B. Flood susceptible mapping and risk area delineation using logistic regression, GIS and remote sensing. J. Spat. Hydrol. 2009, 9, 1-18.

23. Haghizadeh, A.; Siahkamari, S.; Haghiabi, A.H.; Rahmati, O. Forecasting flood-prone areas using shannon's entropy model. J. Earth Syst. Sci. 2017, 126, 39. [CrossRef]

24. Rahmati, O.; Zeinivand, H.; Besharat, M. Flood hazard zoning in Yasooj region, Iran, using GIS and multi-criteria decision analysis. Geomat. Nat. Hazards Risk 2016, 7, 1000-1017. [CrossRef]

25. Termeh, S.V.R.; Kornejady, A.; Pourghasemi, H.R.; Keesstra, S. Flood susceptibility mapping using novel ensembles of adaptive neuro fuzzy inference system and metaheuristic algorithms. Sci. Total Environ. 2018, 615, 438-451. [CrossRef] [PubMed]

26. Ahmadlou, M.; Karimi, M.; Alizadeh, S.; Shirzadi, A.; Parvinnejhad, D.; Shahabi, H.; Panahi, M. Flood susceptibility assessment using integration of adaptive network-based fuzzy inference system (ANFIS) and biogeography-based optimization (BBO) and bat algorithms (BA). Geocarto Int. 2018, 1-21. [CrossRef]

27. Khosravi, K.; Shahabi, H.; Pham, B.T.; Adamawoski, J.; Shirzadi, A.; Pradhan, B.; Dou, J.; Ly, H.-B.; Gróf, G.; Ho, H.L.; et al. A comparative assessment of flood susceptibility modeling using multi-criteria decision-making analysis and machine learning methods. J. Hydrol. 2019, 573, 311-323. [CrossRef]

28. Arabameri, A.; Rezaei, K.; Cerdà, A.; Conoscenti, C.; Kalantari, Z. A comparison of statistical methods and multi-criteria decision making to map flood Hazard susceptibility in Northern Iran. Sci. Total Environ. 2019, 660, 443-458. [CrossRef] 
29. Chen, W.; Shirzadi, A.; Shahabi, H.; Ahmad, B.B.; Zhang, S.; Hong, H.; Zhang, N. A novel hybrid artificial intelligence approach based on the rotation forest ensemble and naïve bayes tree classifiers for a landslide susceptibility assessment in Langao County, China. Geomat. Nat. Hazards Risk 2017, 8, 1955-1977. [CrossRef]

30. Chen, W.; Shahabi, H.; Shirzadi, A.; Li, T.; Guo, C.; Hong, H.; Li, W.; Pan, D.; Hui, J.; Ma, M. A novel ensemble approach of bivariate statistical-based logistic model tree classifier for landslide susceptibility assessment. Geocarto Int. 2018, 33, 1398-1420. [CrossRef]

31. Pham, B.T.; Shirzadi, A.; Bui, D.T.; Prakash, I.; Dholakia, M. A hybrid machine learning ensemble approach based on a radial basis function neural network and rotation forest for landslide susceptibility modeling: A case study in the Himalayan area, India. Int. J. Sediment. Res. 2018, 33, 157-170. [CrossRef]

32. Abedini, M.; Ghasemian, B.; Shirzadi, A.; Shahabi, H.; Chapi, K.; Pham, B.T.; Bin Ahmad, B.; Tien Bui, D. A novel hybrid approach of bayesian logistic regression and its ensembles for landslide susceptibility assessment. Geocarto Int. 2018, 1-31. [CrossRef]

33. Jaafari, A.; Panahi, M.; Pham, B.T.; Shahabi, H.; Bui, D.T.; Rezaie, F.; Lee, S. Meta optimization of an adaptive neuro-fuzzy inference system with grey wolf optimizer and biogeography-based optimization algorithms for spatial prediction of landslide susceptibility. Catena 2019, 175, 430-445. [CrossRef]

34. Nguyen, V.V.; Pham, B.T.; Vu, B.T.; Prakash, I.; Jha, S.; Shahabi, H.; Shirzadi, A.; Ba, D.N.; Kumar, R.; Chatterjee, J.M. Hybrid machine learning approaches for landslide susceptibility modeling. Forests 2019, 10, 157. [CrossRef]

35. Tien Bui, D.; Shahabi, H.; Omidvar, E.; Shirzadi, A.; Geertsema, M.; Clague, J.J.; Khosravi, K.; Pradhan, B.; Pham, B.T.; Chapi, K. Shallow landslide prediction using a novel hybrid functional machine learning algorithm. Remote Sens. 2019, 11, 931. [CrossRef]

36. Zhang, T.; Han, L.; Chen, W.; Shahabi, H. Hybrid integration approach of entropy with logistic regression and support vector machine for landslide susceptibility modeling. Entropy 2018, 20, 884. [CrossRef]

37. Chen, W.; Shahabi, H.; Zhang, S.; Khosravi, K.; Shirzadi, A.; Chapi, K.; Pham, B.; Zhang, T.; Zhang, L.; Chai, $\mathrm{H}$. Landslide susceptibility modeling based on GIS and novel bagging-based kernel logistic regression. Appl. Sci. 2018, 8, 2540. [CrossRef]

38. Chen, W.; Peng, J.; Hong, H.; Shahabi, H.; Pradhan, B.; Liu, J.; Zhu, A.-X.; Pei, X.; Duan, Z. Landslide susceptibility modelling using GIS-based machine learning techniques for Chongren County, Jiangxi province, China. Sci. Total Environ. 2018, 626, 1121-1135. [CrossRef] [PubMed]

39. Chen, W.; Shahabi, H.; Shirzadi, A.; Hong, H.; Akgun, A.; Tian, Y.; Liu, J.; Zhu, A.-X.; Li, S. Novel hybrid artificial intelligence approach of bivariate statistical-methods-based kernel logistic regression classifier for landslide susceptibility modeling. Bull. Eng. Geol. Environ. 2018, 1-23. [CrossRef]

40. Shadman Roodposhti, M.; Aryal, J.; Shahabi, H.; Safarrad, T. Fuzzy shannon entropy: A hybrid GIS-based landslide susceptibility mapping method. Entropy 2016, 18, 343. [CrossRef]

41. Pham, B.T.; Prakash, I.; Khosravi, K.; Chapi, K.; Trinh, P.T.; Ngo, T.Q.; Hosseini, S.V.; Bui, D.T. A comparison of support vector machines and bayesian algorithms for landslide susceptibility modelling. Geocarto Int. 2018, 1-23. [CrossRef]

42. Shirzadi, A.; Solaimani, K.; Roshan, M.H.; Kavian, A.; Chapi, K.; Shahabi, H.; Keesstra, S.; Ahmad, B.B.; Bui, D.T. Uncertainties of prediction accuracy in shallow landslide modeling: Sample size and raster resolution. Catena 2019, 178, 172-188. [CrossRef]

43. He, Q.; Shahabi, H.; Shirzadi, A.; Li, S.; Chen, W.; Wang, N.; Chai, H.; Bian, H.; Ma, J.; Chen, Y. Landslide spatial modelling using novel bivariate statistical based naïve bayes, RBF classifier, and RBF network machine learning algorithms. Sci. Total Environ. 2019, 663, 1-15. [CrossRef]

44. Hong, H.; Shahabi, H.; Shirzadi, A.; Chen, W.; Chapi, K.; Ahmad, B.B.; Roodposhti, M.S.; Hesar, A.Y.; Tian, Y.; Bui, D.T. Landslide susceptibility assessment at the Wuning area, China: A comparison between multi-criteria decision making, bivariate statistical and machine learning methods. Nat. Hazards 2019, 96, 173-212. [CrossRef]

45. Chen, W.; Panahi, M.; Tsangaratos, P.; Shahabi, H.; Ilia, I.; Panahi, S.; Li, S.; Jaafari, A.; Ahmad, B.B. Applying population-based evolutionary algorithms and a neuro-fuzzy system for modeling landslide susceptibility. Catena 2019, 172, 212-231. [CrossRef]

46. Chen, W.; Zhang, S.; Li, R.; Shahabi, H. Performance evaluation of the GIS-based data mining techniques of best-first decision tree, random forest, and naïve bayes tree for landslide susceptibility modeling. Sci. Total Environ. 2018, 644, 1006-1018. [CrossRef] [PubMed] 
47. Shirzadi, A.; Soliamani, K.; Habibnejhad, M.; Kavian, A.; Chapi, K.; Shahabi, H.; Chen, W.; Khosravi, K.; Thai Pham, B.; Pradhan, B. Novel GIS based machine learning algorithms for shallow landslide susceptibility mapping. Sensors 2018, 18, 3777. [CrossRef]

48. Shirzadi, A.; Shahabi, H.; Chapi, K.; Bui, D.T.; Pham, B.T.; Shahedi, K.; Ahmad, B.B. A comparative study between popular statistical and machine learning methods for simulating volume of landslides. Catena 2017, 157, 213-226. [CrossRef]

49. Shahabi, H.; Hashim, M. Landslide susceptibility mapping using GIS-based statistical models and remote sensing data in tropical environment. Sci. Rep. 2015, 5, 9899. [CrossRef]

50. Jaafari, A.; Zenner, E.K.; Panahi, M.; Shahabi, H. Hybrid artificial intelligence models based on a neuro-fuzzy system and metaheuristic optimization algorithms for spatial prediction of wildfire probability. Agric. Meteorol. 2019, 266, 198-207. [CrossRef]

51. Taheri, K.; Shahabi, H.; Chapi, K.; Shirzadi, A.; Gutiérrez, F.; Khosravi, K. Sinkhole susceptibility mapping: A comparison between bayes-based machine learning algorithms. Land Degrad. Dev. 2019, 30, 730-745. [CrossRef]

52. Roodposhti, M.S.; Safarrad, T.; Shahabi, H. Drought sensitivity mapping using two one-class support vector machine algorithms. Atmos. Res. 2017, 193, 73-82. [CrossRef]

53. Azareh, A.; Rahmati, O.; Rafiei-Sardooi, E.; Sankey, J.B.; Lee, S.; Shahabi, H.; Ahmad, B.B. Modelling gully-erosion susceptibility in a semi-arid region, Iran: Investigation of applicability of certainty factor and maximum entropy models. Sci. Total Environ. 2019, 655, 684-696. [CrossRef] [PubMed]

54. Tien Bui, D.; Shirzadi, A.; Shahabi, H.; Chapi, K.; Omidavr, E.; Pham, B.T.; Talebpour Asl, D.; Khaledian, H.; Pradhan, B.; Panahi, M. A novel ensemble artificial intelligence approach for gully erosion mapping in a semi-arid watershed (Iran). Sensors 2019, 19, 2444. [CrossRef] [PubMed]

55. Miraki, S.; Zanganeh, S.H.; Chapi, K.; Singh, V.P.; Shirzadi, A.; Shahabi, H.; Pham, B.T. Mapping groundwater potential using a novel hybrid intelligence approach. Water Resour. Manag. 2019, 33, 281-302. [CrossRef]

56. Rahmati, O.; Naghibi, S.A.; Shahabi, H.; Bui, D.T.; Pradhan, B.; Azareh, A.; Rafiei-Sardooi, E.; Samani, A.N.; Melesse, A.M. Groundwater spring potential modelling: Comprising the capability and robustness of three different modeling approaches. J. Hydrol. 2018, 565, 248-261. [CrossRef]

57. Khosravi, K.; Panahi, M.; Tien Bui, D. Spatial prediction of groundwater spring potential mapping based on adaptive neuro-fuzzy inference system and metaheuristic optimization. Hydrol. Earth Syst. Sci. 2018, 22, 4771-4792. [CrossRef]

58. Pham, B.T.; Prakash, I.; Singh, S.K.; Shirzadi, A.; Shahabi, H.; Bui, D.T. Landslide susceptibility modeling using reduced error pruning trees and different ensemble techniques: Hybrid machine learning approaches. CATENA 2019, 175, 203-218. [CrossRef]

59. Pradhan, B.; Abokharima, M.H.; Jebur, M.N.; Tehrany, M.S. Land subsidence susceptibility mapping at Kinta valley (Malaysia) using the evidential belief function model in GIS. Nat. Hazards 2014, 73, 1019-1042. [CrossRef]

60. Chen, W.; Pradhan, B.; Li, S.; Shahabi, H.; Rizeei, H.M.; Hou, E.; Wang, S. Novel hybrid integration approach of bagging-based fisher's linear discriminant function for groundwater potential analysis. Nat. Resour. Res. 2019, 1-20. [CrossRef]

61. Sadeghi-Pouya, A.; Nouri, J.; Mansouri, N.; Kia-Lashaki, A. An indexing approach to assess flood vulnerability in the western coastal cities of Mazandaran, Iran. Int. J. Disaster Risk Reduct. 2017, 22, 304-316. [CrossRef]

62. Manandhar, B.; Balla, M.K.; Awal, R.; Pradhan, B.M. Floodplain Analysis and Risk Assessment of Lothar Khola (Stream). In Proceedings of the 11th ESRI India User Conference, Noida, India, 21-22 April 2010.

63. Merz, B.; Thieken, A.; Gocht, M. Flood Risk Mapping at the Local Scale: Concepts and Challenges. In Flood Risk Management in Europe; Springer: Dordrecht, The Netherlands, 2007; pp. 231-251.

64. Tehrany, M.S.; Pradhan, B.; Jebur, M.N. Flood susceptibility mapping using a novel ensemble weights-of-evidence and support vector machine models in GIS. J. Hydrol. 2014, 512, 332-343. [CrossRef]

65. Pourghasemi, H.R.; Beheshtirad, M. Assessment of a data-driven evidential belief function model and GIS for groundwater potential mapping in the Koohrang watershed, Iran. Geocarto Int. 2015, 30, 662-685. [CrossRef]

66. O'brien, R.M. A caution regarding rules of thumb for variance inflation factors. Qual. Quant. 2007, 41, 673-690. [CrossRef] 
67. Yalcin, A.; Reis, S.; Aydinoglu, A.; Yomralioglu, T. A GIS-based comparative study of frequency ratio, analytical hierarchy process, bivariate statistics and logistics regression methods for landslide susceptibility mapping in Trabzon, NE Turkey. Catena 2011, 85, 274-287. [CrossRef]

68. Bednarik, M.; Magulová, B.; Matys, M.; Marschalko, M. Landslide susceptibility assessment of the Kral'ovany-liptovský Mikuláš railway case study. Phys. Chem. Earthparts A/B/C 2010, 35, 162-171. [CrossRef]

69. Gokceoglu, C.; Sonmez, H.; Nefeslioglu, H.A.; Duman, T.Y.; Can, T. The 17 march 2005 kuzulu landslide (Sivas, Turkey) and landslide-susceptibility map of its near vicinity. Eng. Geol. 2005, 81, 65-83. [CrossRef]

70. Moore, I.D.; Grayson, R.; Ladson, A. Digital terrain modelling: A review of hydrological, geomorphological, and biological applications. Hydrol. Process. 1991, 5, 3-30. [CrossRef]

71. Glenn, E.P.; Morino, K.; Nagler, P.L.; Murray, R.S.; Pearlstein, S.; Hultine, K.R. Roles of saltcedar (tamarix spp.) and capillary rise in salinizing a non-flooding terrace on a flow-regulated desert river. J. Arid Environ. 2012, 79, 56-65. [CrossRef]

72. Kia, M.B.; Pirasteh, S.; Pradhan, B.; Mahmud, A.R.; Sulaiman, W.N.A.; Moradi, A. An artificial neural network model for flood simulation using GIS: Johor river Basin, Malaysia. Environ. Earth Sci. 2012, 67, 251-264. [CrossRef]

73. Tehrany, M.S.; Lee, M.-J.; Pradhan, B.; Jebur, M.N.; Lee, S. Flood susceptibility mapping using integrated bivariate and multivariate statistical models. Environ. Earth Sci. 2014, 72, 4001-4015. [CrossRef]

74. Çelik, H.E.; Coskun, G.; Cigizoglu, H.K.; Ağıralioğlu, N.; Aydın, A.; Esin, A.I. The analysis of 2004 flood on Kozdere stream in Istanbul. Nat. Hazards 2012, 63, 461-477. [CrossRef]

75. Srivastava, O.S.; Denis, D.; Srivastava, S.K.; Kumar, M.; Kumar, N. Morphometric analysis of a semi urban watershed, Trans Yamuna, draining at allahabad using cartosat (DEM) data and GIS. Int. J. Eng. Sci. (Ijes) 2014, 3, 71-79.

76. Mongelli, G.; Salvemini, A. Caratterizzazione Geolitologica e Carta della Permeabilità Della Puglia Settentrionale; Dipartimento di Ingegneria e Fisica Dell'Ambiente e Gruppo Nazionale per la Difesa dalle Catastrofi Idrogeologiche, Univ. della Basilicata, Potenza: Sicily, Italy, 14 October 1994.

77. Bui, D.T.; Panahi, M.; Shahabi, H.; Singh, V.P.; Shirzadi, A.; Chapi, K.; Khosravi, K.; Chen, W.; Panahi, S.; Li, S. Novel hybrid evolutionary algorithms for spatial prediction of floods. Sci. Rep. 2018, 8, 15364. [CrossRef] [PubMed]

78. Shahabi, H.; Ahmad, B.B.; Mokhtari, M.H.; Zadeh, M.A. Detection of urban irregular development and green space destruction using normalized difference vegetation index (NDVI), principal component analysis (PCA) and post classification methods: A case study of Saqqez city. Int. J. Phys. Sci. 2012, 7, 2587-2595.

79. Tien Bui, D.; Khosravi, K.; Li, S.; Shahabi, H.; Panahi, M.; Singh, V.; Chapi, K.; Shirzadi, A.; Panahi, S.; Chen, W. New hybrids of anfis with several optimization algorithms for flood susceptibility modeling. Water 2018, 10, 1210. [CrossRef]

80. Dempster, A.P. Upper and lower probability inferences for families of hypotheses with monotone density ratios. Ann. Math. Stat. 1969, 40, 953-969. [CrossRef]

81. Shafer, G. A Mathematical Theory of Evidence; Princeton University Press: Princeton, NJ, USA, 1976; Volume 42.

82. Park, N.-W. Application of dempster-shafer theory of evidence to GIS-based landslide susceptibility analysis. Environ. Earth Sci. 2011, 62, 367-376. [CrossRef]

83. Carranza, E.J.M.; Hale, M. Evidential belief functions for data-driven geologically constrained mapping of gold potential, Pbaguio district, Philippines. Ore Geol. Rev. 2003, 22, 117-132. [CrossRef]

84. Chen, W.; Zhao, X.; Shahabi, H.; Shirzadi, A.; Khosravi, K.; Chai, H.; Zhang, S.; Zhang, L.; Ma, J.; Chen, Y. Spatial prediction of landslide susceptibility by combining evidential belief function, logistic regression and logistic model tree. Geocarto Int. 2019, 1-25. [CrossRef]

85. Shirzadi, A.; Saro, L.; Joo, O.H.; Chapi, K. A GIS-based logistic regression model in rock-fall susceptibility mapping along a mountainous road: Salavat Abad case study, Kurdistan, Iran. Nat. Hazards 2012, 64, 1639-1656. [CrossRef]

86. Shahabi, H.; Khezri, S.; Ahmad, B.B.; Hashim, M. Landslide susceptibility mapping at central zab basin, Iran: A comparison between analytical hierarchy process, frequency ratio and logistic regression models. Catena 2014, 115, 55-70. [CrossRef]

87. Umar, Z.; Pradhan, B.; Ahmad, A.; Jebur, M.N.; Tehrany, M.S. Earthquake induced landslide susceptibility mapping using an integrated ensemble frequency ratio and logistic regression models in west Sumatera province, Indonesia. Catena 2014, 118, 124-135. [CrossRef] 
88. Hosmer, D.W.; Lemeshow, S. Applied Logistic Regression.(sl); Wiley: Hoboken, NJ, USA, 2000.

89. Papadopoulou-Vrynioti, K.; Bathrellos, G.D.; Skilodimou, H.D.; Kaviris, G.; Makropoulos, K. Karst collapse susceptibility mapping considering peak ground acceleration in a rapidly growing urban area. Eng. Geol. 2013, 158, 77-88. [CrossRef]

90. Pourghasemi, H.R.; Mohammady, M.; Pradhan, B. Landslide susceptibility mapping using index of entropy and conditional probability models in GIS: Safarood basin, Iran. Catena 2012, 97, 71-84. [CrossRef]

91. Chung, C.-J.F.; Fabbri, A.G. Validation of spatial prediction models for landslide hazard mapping. Nat. Hazards 2003, 30, 451-472. [CrossRef]

92. Bui, D.T.; Pradhan, B.; Lofman, O.; Revhaug, I.; Dick, O.B. Landslide susceptibility mapping at Hoa Binh province (Vietnam) using an adaptive neuro-fuzzy inference system and gis. Comput. Geosci. 2012, 45, 199-211.

93. Pradhan, B. A comparative study on the predictive ability of the decision tree, support vector machine and neuro-fuzzy models in landslide susceptibility mapping using GIS. Comput. Geosci. 2013, 51, 350-365. [CrossRef]

94. Brenning, A. Spatial prediction models for landslide hazards: Review, comparison and evaluation. Nat. Hazards Earth Syst. Sci. 2005, 5, 853-862. [CrossRef]

95. Bui, D.T.; Lofman, O.; Revhaug, I.; Dick, O. Landslide susceptibility analysis in the Hoa Binh province of Vietnam using statistical index and logistic regression. Nat. Hazards 2011, 59, 1413. [CrossRef]

96. Maier, H.R.; Dandy, G.C. Neural networks for the prediction and forecasting of water resources variables: A review of modelling issues and applications. Environ. Model. Softw. 2000, 15, 101-124. [CrossRef]

97. Chen, W.; Hong, H.; Li, S.; Shahabi, H.; Wang, Y.; Wang, X.; Ahmad, B.B. Flood susceptibility modelling using novel hybrid approach of reduced-error pruning trees with bagging and random subspace ensembles. J. Hydrol. 2019, 575, 864-873. [CrossRef]

98. Walley, P. Belief function representations of statistical evidence. Ann. Stat. 1987, 15, 1439-1465. [CrossRef]

99. Carranza, E.J.M.; Van Ruitenbeek, F.; Hecker, C.; van der Meijde, M.; van der Meer, F.D. Knowledge-guided data-driven evidential belief modeling of mineral prospectivity in Cabo De Gata, SE Spain. Int. J. Appl. Earth Obs. Geoinf. 2008, 10, 374-387. [CrossRef]

100. Bui, D.T.; Pradhan, B.; Lofman, O.; Revhaug, I.; Dick, O.B. Spatial prediction of landslide hazards in Hoa Binh province (Vietnam): A comparative assessment of the efficacy of evidential belief functions and fuzzy logic models. Catena 2012, 96, 28-40.

101. Razavi Termeh, V.; Malek, M. Flood susceptibility mapping using ensemble of evidential belief (EBF) function with analytical hierarchy process (AHP) (Case study: Jhrom township). Geospat. Eng. J. 2017, 8, 1-15.

102. Tehrany, M.S.; Kumar, L. The application of a dempster-shafer-based evidential belief function in flood susceptibility mapping and comparison with frequency ratio and logistic regression methods. Environ. Earth Sci. 2018, 77, 490. [CrossRef]

103. Donati, L.; Turrini, M. An objective method to rank the importance of the factors predisposing to landslides with the GIS methodology: Application to an area of the Apennines (Valnerina; Perugia, Italy). Eng. Geol. 2002, 63, 277-289. [CrossRef]

(C) 2019 by the authors. Licensee MDPI, Basel, Switzerland. This article is an open access article distributed under the terms and conditions of the Creative Commons Attribution (CC BY) license (http://creativecommons.org/licenses/by/4.0/). 